Washington University School of Medicine Digital Commons@Becker

$11-8-2021$

\title{
Synaptic Zn 2+ potentiates the effects of cocaine on striatal dopamine neurotransmission and behavior
}

\author{
Juan L. Gomez \\ National Institute on Drug Abuse Intramural Research Program \\ Marco Pignatelli \\ Washington University School of Medicine in St. Louis \\ et al
}

Follow this and additional works at: https://digitalcommons.wustl.edu/open_access_pubs Please let us know how this document benefits you.

\section{Recommended Citation}

Gomez, Juan L.; Pignatelli, Marco; and et al, "Synaptic Zn 2+ potentiates the effects of cocaine on striatal dopamine neurotransmission and behavior." Translational Psychiatry. 11, 1. 570 (2021).

https://digitalcommons.wustl.edu/open_access_pubs/11035

This Open Access Publication is brought to you for free and open access by Digital Commons@Becker. It has been accepted for inclusion in Open Access Publications by an authorized administrator of Digital Commons@Becker. For more information, please contact vanam@wustl.edu. 


\title{
Synaptic $\mathrm{Zn}^{2+}$ potentiates the effects of cocaine on striatal dopamine neurotransmission and behavior
}

\author{
Juan L. Gomez ${ }^{1}$, Jordi Bonaventura (iD) ${ }^{1}$, Jacqueline Keighron ${ }^{2}$, Kelsey M. Wright (D) ${ }^{1}$, Dondre L. Marable ${ }^{1}$, Lionel A. Rodriguez ${ }^{1}$, \\ Sherry Lam ${ }^{1}$, Meghan L. Carlton ${ }^{1}$, Randall J. Ellis ${ }^{1}$, Chloe J. Jordan (iD ${ }^{3}$, Guo-hua Bi ${ }^{3}$, Oscar Solis ${ }^{1}$, Marco Pignatelli ${ }^{4}$, \\ Michael J. Bannon (D) ${ }^{5}$, Zheng-Xiong $\mathrm{Xi}^{3}$, Gianluigi Tanda (D) $^{2}$ and Michael Michaelides (iD ${ }^{1,6 \bowtie}$
}

This is a U.S. government work and not under copyright protection in the U.S.; foreign copyright protection may apply 2021

Cocaine binds to the dopamine (DA) transporter (DAT) to regulate cocaine reward and seeking behavior. Zinc ( $\mathrm{Zn}^{2+}$ ) also binds to the DAT, but the in vivo relevance of this interaction is unknown. We found that $\mathrm{Zn}^{2+}$ concentrations in postmortem brain (caudate) tissue from humans who died of cocaine overdose were significantly lower than in control subjects. Moreover, the level of striatal $\mathrm{Zn}^{2+}$ content in these subjects negatively correlated with plasma levels of benzoylecgonine, a cocaine metabolite indicative of recent use. In mice, repeated cocaine exposure increased synaptic $\mathrm{Zn}^{2+}$ concentrations in the caudate putamen (CPu) and nucleus accumbens (NAc). Cocaine-induced increases in $\mathrm{Zn}^{2+}$ were dependent on the $\mathrm{Zn}^{2+}$ transporter 3 (ZnT3), a neuronal $\mathrm{Zn}^{2+}$ transporter localized to synaptic vesicle membranes, as ZnT3 knockout (KO) mice were insensitive to cocaine-induced increases in striatal $\mathrm{Zn}^{2+}$. ZnT3 KO mice showed significantly lower electrically evoked DA release and greater DA clearance when exposed to cocaine compared to controls. ZnT3 KO mice also displayed significant reductions in cocaine locomotor sensitization, conditioned place preference (CPP), self-administration, and reinstatement compared to control mice and were insensitive to cocaine-induced increases in striatal DAT binding. Finally, dietary $\mathrm{Zn}^{2+}$ deficiency in mice resulted in decreased striatal $\mathrm{Zn}^{2+}$ content, cocaine locomotor sensitization, CPP, and striatal DAT binding. These results indicate that cocaine increases synaptic $Z n^{2+}$ release and turnover/metabolism in the striatum, and that synaptically released $\mathrm{Zn}^{2+}$ potentiates the effects of cocaine on striatal DA neurotransmission and behavior and is required for cocaine-primed reinstatement. In sum, these findings reveal new insights into cocaine's pharmacological mechanism of action and suggest that $\mathrm{Zn}^{2+}$ may serve as an environmentally derived regulator of DA neurotransmission, cocaine pharmacodynamics, and vulnerability to cocaine use disorders.

Translational Psychiatry (2021)11:570; https://doi.org/10.1038/s41398-021-01693-0

\section{INTRODUCTION}

Zinc $\left(\mathrm{Zn}^{2+}\right)$ is an essential trace element necessary for normal brain function [1-6]. Within the brain it exists in two forms; a "fixed", protein-bound form, which serves as a catalytic co-factor or as a structural component to $\mathrm{Zn}^{2+}$ binding proteins, and comprises $\sim 90 \%$ of total brain concentration, or a "free", or labile/ chelatable form, comprising $\sim 10 \%$ of total brain concentration. Labile $\mathrm{Zn}^{2+}$ is also referred to as "synaptic" $\mathrm{Zn}^{2+}$ as it is localized to synaptic vesicles in a subset of glutamatergic neurons, also referred to as "zincergic" neurons [7]. Synaptic $\mathrm{Zn}^{2+}$ is found in several regions such as cortex (Ctx, layers 2/3, 5, and 6), hippocampus, striatum, amygdala and is generally not present in thalamus $[7,8]$.

Synaptic $\mathrm{Zn}^{2+}$ levels are dependent on the $\mathrm{Zn}^{2+}$ transporter 3 (ZnT3) $[9,10]$, a neuronal-specific $Z n^{2+}$ transporter localized to the membrane of synaptic vesicles. ZnT3 knockout (KO) mice lack the ability to package $\mathrm{Zn}^{2+}$ into these vesicles and consequently lack synaptic $\mathrm{Zn}^{2+}$ release $[9,10]$. ZnT3 KO mice are viable, fertile, and do not show major behavioral abnormalities across spatial learning, memory, or sensorimotor tasks, though they do exhibit small deficits in skilled reaching tasks [11, 12], fear learning [13], and sensory deficits $[14,15]$.

In terms of function, synaptic $\mathrm{Zn}^{2+}$ is released upon neuronal activation, serves as a key regulator of neurotransmitter signaling, and as such has also been referred to as a neurotransmitter [1-6]. Tonic extracellular $\mathrm{Zn}^{2+}$ concentrations are estimated to be at $<25 \mathrm{nM}$ [16]. However, upon physiological zincergic neuron activation and subsequent release, phasic $\mathrm{Zn}^{2+}$ concentrations can increase up to $10 \mu \mathrm{M}$ [17]. In this way, $\mathrm{Zn}^{2+}$ is thought to exert various effects on neurotransmission by binding to synaptic proteins that contain either low- or high-affinity $\mathrm{Zn}^{2+}$-binding sites [6]. One such protein is the dopamine transporter (DAT), which contains four high-affinity $\mathrm{Zn}^{2+-}$ binding sites on its extracellular domain [18-22].

Studies have shown that cocaine binds to the DAT to inhibit synaptic DA reuptake, which leads to an increase of extracellular

\footnotetext{
${ }^{1}$ Biobehavioral Imaging and Molecular Neuropsychopharmacology Unit, National Institute on Drug Abuse Intramural Research Program, Baltimore, MD 21224, USA. ${ }^{2}$ Medication Development Program, National Institute on Drug Abuse Intramural Research Program, Baltimore, MD 21224, USA. ${ }^{3}$ Addiction Biology Unit, National Institute on Drug Abuse Intramural Research Program, Baltimore, MD 21224, USA. ${ }^{4}$ Department of Psychiatry and Taylor Family Institute for Innovative Psychiatric Research, Washington University School of Medicine, St Louis, MO 63110, USA. ${ }^{5}$ Department of Pharmacology, Wayne State University School of Medicine, Detroit, MI 48201, USA. ${ }^{6}$ Department of Psychiatry and

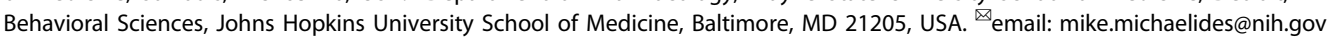


DA [23]. This mechanism underlies the direct subjective responses that accompany cocaine use [24] and is critical to cocaine selfadministration (SA) in laboratory models, and cocaine reward and abuse liability in humans [25]. In vitro assays have shown that when $\mathrm{Zn}^{2+}$ binds to the DAT it promotes a conformation that inhibits DA uptake and, when cocaine is present, $\mathrm{Zn}^{2+}$ can increase cocaine's affinity and can modulate its potency to inhibit DA uptake [18-22]. Interestingly, synaptic $\mathrm{Zn}^{2+}$ is present in the striatum $[26,27]$ where the DAT is found in the highest concentration [28], and synaptic $\mathrm{Zn}^{2+}$ depletion in this region improves motor deficits and memory impairments caused by loss of striatal DAergic fibers [29]. These prior studies suggest that synaptic $\mathrm{Zn}^{2+}$ may modulate in vivo DAT function and cocaineDAT pharmacodynamic interactions in the striatum. However, the extent to which such interactions occur is unclear.

In addition to $\mathrm{ZnT3}$, synaptic $\mathrm{Zn}^{2+}$ levels also depend on the environmental availability of $\mathrm{Zn}^{2+}$ which is obtained exclusively via the diet. Consequently, dietary factors which limit $\mathrm{Zn}^{2+}$ intake influence both synaptic $\mathrm{Zn}^{2+}$ levels and $\mathrm{ZnT3}$ expression [30, 31]. In fact, as the body lacks a specialized system for its storage, $\mathrm{Zn}^{2+}$ needs to be consumed continuously to avoid a state of deficiency which itself can have profound changes in both the periphery as well as in brain function [32]. Human drug users generally do not follow a lifestyle that prioritizes nutritional needs and are known to exhibit nutritional deficiencies including dysregulated blood and hair $\mathrm{Zn}^{2+}$ content [33-38]. However, whether such deficits are involved in the neurobiological changes associated with cocaine use or use of other drugs is unknown.

\section{METHODS \\ Subjects}

De-identified postmortem human brain specimens were collected during the routine autopsy process as described in detail previously $[39,40]$. Briefly, the cause and manner of death were determined by forensic pathologists following medico-legal investigations that evaluated the circumstances of death including medical records, police reports, autopsy results, and toxicological data. Inclusion in the cocaine cohort ( $n=20 ; 10$ Caucasian, 10 African-American) was based on cocaine abuse as the cause of death, a documented history of drug abuse, and a toxicology positive for high levels of the cocaine metabolite benzoylecgonine and, in most cases, the short-lived cocaine adulterant levamisole, both indicative of recent cocaine use prior to death. Control subjects ( $n=20 ; 10$ Caucasian, 10 African-American) died as a result of cardiovascular disease or gunshot wound, had no documented history of drug abuse, and tested negative for cocaine and other drugs of abuse. Exclusion criteria for the study included a known history of neurological or psychiatric illness, death by suicide, estimated postmortem interval exceeding $20 \mathrm{~h}$, evidence of neuropathology (e.g., encephalitis, stroke), or chronic illness (e.g., cirrhosis, cancer, HIV, prolonged hospitalization). The final groups did not differ with regard to age for race, nor with regard to brain $\mathrm{pH}$, a well-established measure of sample quality and perimortem agonal state [41]. Tissue from one cocaine user was not included due to very high cocaine metabolite levels.

Given that the human tissue samples available consisted only of males, and therefore all human data were limited to this sex, we focused on male mice for all other mechanistic experiments. Male C57BI/6J mice were acquired from Jackson Labs at 8 weeks of age. Breeding pairs of S/c30a3 (ZnT3) KO mice were obtained from Dr. Thanos Tzounopoulos at the University of Pittsburgh and bred at the National Institute on Drug Abuse (NIDA) (Baltimore, MD) on a C57BI/6J background. Mice were genotyped by Transnetyx (Cordova, TN). All mice were male and matched for age and weight. Mice were single-housed during experimental testing in a temperature and humidity-controlled environment on a regular light cycle (on at $7 \mathrm{am}$ and off at $7 \mathrm{pm}$ ). Food and water were available ad libitum and mice were acclimated prior to any behavioral procedures by handling. All experimental procedures were carried out in accordance with the National Institutes of Health Guide for the Care and Use of Laboratory Animals and were approved by the Animal Care and Use Committee of NIDA.

\section{Total reflection X-ray spectroscopy (TXRF)}

Tissue samples were collected and weighed in $1.5 \mathrm{ml}$ Eppendorf tubes. The weight of the tissue was directly used to calculate element concentrations in $\mu \mathrm{g} / \mathrm{kg}$ units. Each tissue sample was dissolved in $100 \mu \mathrm{L}$ of nitric acid (Sigma: NX0408) with $2 \mu \mathrm{L}$ of a gallium standard (conc. 1000 ppm). Each sample was assessed in duplicate for TXRF elemental analysis using an S2 Picofox (Bruker, Billerica, MA). This instrument exposes the sample to an $X$-ray beam and measures fluorescence radiation specific to the element(s) of interest. Human samples were prepared from postmortem tissue collected from the anterior caudate. Wild-type (WT) or ZnT3 KO mice received either saline, a single cocaine injection $(20 \mathrm{mg} / \mathrm{kg}$, i.p), or 8 repeated daily cocaine ( $20 \mathrm{mg} / \mathrm{kg}$, i.p) injections and were euthanized $24 \mathrm{~h}$ after the last injection. Mice fed the $30 \mathrm{ppm}$ and $5 \mathrm{ppm} \mathrm{Zn}^{2+}$ diets were exposed to each respective diet for 35 days and then euthanized. Mouse samples were prepared by slicing flash-frozen tissue on a cryostat $(100 \mu \mathrm{m}$ sections from Bregma 1.00 to $0.00 \mathrm{~mm}$ ) or dissecting the Ctx and striatum from each section.

\section{Synchrotron X-ray fluorescence microspectroscopy ( $\mu$ XRFS)}

Brain concentrations and distributions of $\mathrm{Zn}^{2+}$ from C57BL/6J mice injected with saline or cocaine $(10 \mathrm{mg} / \mathrm{kg}$, i.p.) every other day for 8 days and euthanized $24 \mathrm{~h}$ after the last injection were measured at the X26a beamline at the National Synchrotron Light Source (NSLS) at Brookhaven National Laboratory (Upton, NY). The synchrotron X-ray beam was tuned to $12 \mathrm{keV}$ using a $\mathrm{Si}(111)$ channel-cut monochromotor. The monochromatic beam was then collimated to $350 \mu \mathrm{m} \times 350 \mu \mathrm{m}$ and then focused to approximately $6 \mu \mathrm{m} \times 10 \mu \mathrm{m}$ using Rh-coated silicon mirrors in a Kirkpatrick-Baez (KB) geometry. The sample was placed at a $45^{\circ}$ angle to the incident X-ray beam and X-ray fluorescence was detected with an energy dispersive, 9-element germanium array detector (Canberra, Meriden, CT) oriented at $90^{\circ}$ to the incident beam. The sample was approximately $6 \mathrm{~cm}$ from the detector. A light microscope objective (Mitutoyo, M Plan Apo 5X) was coupled to a digital CCD camera for sample viewing. Energy dispersive spectra were collected by raster-scanning the sample through the X-ray beam using a dwell time of $0.3 \mathrm{~s} /$ pixel and a step size of $10 \mu \mathrm{m}$. $\mathrm{Zn} \mathrm{Ka}$, fluorescence counts were then extracted from background-corrected energy dispersive spectra. All data were normalized to variations in incident photon flux by normalizing to changes in 10 measured by ion chamber upstream of the KB optics. XRFS calibration standards on Nuclepore polycarbonate aerosol membranes expressing known $( \pm 5 \%)$ concentrations of $\mathrm{Zn}\left(48.4 \mu \mathrm{g} / \mathrm{cm}^{2}\right)$ were also imaged in parallel to the samples (Micromatter, Vancouver, BC) and used to express results as $\mu \mathrm{g} / \mathrm{cm}^{2}$. Image analysis was carried out using ImageJ (National Institutes of Health, Bethesda, MD). Regions of interest (ROI) were drawn onto the $\mathrm{Ctx}$, caudate putamen ( $\mathrm{CPu})$, nucleus accumbens (NAc), and measurements for each ROI were obtained.

\section{Zinc-selenium autometallography ( $\mathrm{ZnSe} \mathrm{AMG}^{\mathrm{AMG}}$}

WT and ZnT3 KO mice were anesthetized with a ketamine-xylazine cocktail (ket $=60 \mathrm{mg} / \mathrm{kg}+\mathrm{xyl}=12 \mathrm{mg} / \mathrm{kg}$ ) and injected (i.p.) with $15 \mathrm{mg} / \mathrm{kg}$ sodium selenite (Sigma Aldrich: 214485) and placed on a heating pad while anesthetized for $60 \mathrm{~min}$. Mice were then perfused with $0.1 \mathrm{M}$ phosphate buffer for $5 \mathrm{~min}$. Brain tissue was dissected, and flash frozen in dry ice cooled isopentane and stored at $-80^{\circ} \mathrm{C}$ until sectioning. Coronal brain sections $(20 \mu \mathrm{m})$ were thaw mounted at the level of the striatum and hippocampus on positively charged glass slides. Slides were stored at $-20^{\circ} \mathrm{C}$ until staining. Slides were loaded in non-metallic staining racks and allowed to reach room temperature. Slides were fixed in $95 \%$ ethanol for $15 \mathrm{~min}$ followed by hydration in $70 \%$ ( $2 \mathrm{~min}$ ) and $50 \%$ ( $2 \mathrm{~min}$ ) ethanol ending in $3 \times 2 \mathrm{~min}$ distilled water rinses. Slides were dipped in $0.5 \%$ gelatin and air dried prior to physical development. Developer was made by mixing Gum Arabic (50\% solution, $100 \mathrm{ml})$, citrate buffer $(2.0 \mathrm{M}, 20 \mathrm{ml})$, hydroquinone $\left(1.7 \mathrm{~g}\right.$ in $\left.30 \mathrm{ml} \mathrm{DDH} \mathrm{D}_{2} \mathrm{O}\right)$, silver lactate $\left(0.22 \mathrm{~g}\right.$ in $\left.30 \mathrm{ml} \mathrm{H}_{2} \mathrm{O}\right)$, and $\mathrm{DDH}_{2} \mathrm{O}(200 \mathrm{ml})$. Developer was poured onto slides, incubated for $60 \mathrm{~min}$ in the dark then quickly checked at $10 \mathrm{~min}$ intervals until sections are dark brown. Slides were washed in slowly flowing tap water $\left(37^{\circ} \mathrm{C}\right)$ for $10 \mathrm{~min}$ to remove gelatin then rinsed $3 \times 2 \mathrm{~min}$ in distilled water. Slides were then incubated in $5 \%$ sodium thiosulphate $(12 \mathrm{~min})$ and rinsed $2 \times 2 \mathrm{~min}$ in distilled water and post-fixed in $70 \%$ ethanol (30 min). Optional counter stain using cresyl violet or toluidine blue $(5 \mathrm{~min})$ followed by rinse $4 \times 30$ s rinse in distilled water. Finally, slides were dehydrated in $95 \%$ ethanol ( $5 \mathrm{~min}$ ), $100 \%$ ethanol $2 \times 5 \mathrm{~min}$, xylene $2 \times 5 \mathrm{~min}$, and coverslipped with permount. Stained sections were imaged using brightfield microscopy. 


\section{${ }^{65} \mathrm{Zn}$ uptake experiments using positron emission} tomography (PET)

WT and ZnT3 KO mice were anesthetized with isoflurane and placed in a prone position on the scanner bed of a nanoScan PET/CT (Mediso, USA) injected intravenously $(\sim 150 \mu \mathrm{L})$ with ${ }^{65} \mathrm{ZnCl}_{2}(\sim 2.2 \mathrm{MBq})$ and PET data were acquired for $2 \mathrm{~h}$ followed by a CT scan. After scanning, animals were returned to their home cage. Scans were repeated on days $1,3,7$, and 14 . For cocaine experiments, $\mathrm{C} 57 \mathrm{Bl} / 6 \mathrm{~J}$ mice were injected with ${ }^{65} \mathrm{ZnCl}_{2}$ as above and then injected immediately with saline or cocaine $(20 \mathrm{mg} / \mathrm{kg}$, i.p). Saline and cocaine injections continued daily for 7 days. Mice were scanned on Day 1 and Day 7 after ${ }^{65} \mathrm{ZnCl}_{2}$ injection as above. In all cases, the PET data were reconstructed and corrected for dead-time and radioactive decay. Qualitative and quantitative assessments of PET images were performed using the PMOD software environment (PMOD Technologies, Zurich Switzerland). Time-activity curves were generated using manually drawn volumes of interest using the $\mathrm{CT}$ image as a reference. Standardized uptake values (SUV) were calculated using the formula SUV(i) $=C(\mathrm{i}) /(\mathrm{ID} \times \mathrm{BW})$ where $\mathrm{C}(\mathrm{i})$ is the activity value at a given time point (in $\mathrm{kBq} / \mathrm{cc}$ ), ID is the injected dose (in $\mathrm{MBq}$ ) and $\mathrm{BW}$ is the animal's body weight (in kg). For voxel-wise analyses we used Statistical Parametric Mapping (SPM12, London, UK) as previously described [42]. First, all the images were co-registered and masked to the reference mouse atlas in PMOD. Regional changes in uptake were assessed relative to global (whole-brain) uptake. For the cocaine experiments, a repeated measures (RM) analysis of variance (ANOVA) model was used that defined saline vs. cocaine-treated mice scanned at 1 and 7 days post ${ }^{65} \mathrm{ZnCl}_{2}$ injection. Images were subtracted after intensity normalization to 100 by the proportional scaling method. After estimation of the statistical model, a contrast (Cocaine $>$ Vehicle) was applied to reveal the effects of interest. These effects were overlaid on the reference MRI. An uncorrected $P$ value of 0.05 with a cluster threshold value of 50 were used as thresholds to determine statistical significance.

\section{Ex vivo ${ }^{65} \mathrm{Zn}$ autoradiography}

One day after the last PET scan, WT and ZnT3 KO mice were euthanized and brain tissue was dissected, flash frozen in isopentane, and stored at $-80^{\circ} \mathrm{C}$ until sectioning. Tissue was sectioned and thaw mounted on positively charged glass slides. Slides were placed on BAS-IP SR 2040 E Super Resolution phosphor screens (GE Healthcare) for 14 days and imaged using a phosphor imager (Typhoon FLA 7000; GE Healthcare).

\section{Radioligand binding assays}

Brains from euthanized C57Bl/6J mice were removed and striata dissected and quickly frozen until use. The tissue was weighed and suspended in ten times (w/v) of ice-cold Tris- $\mathrm{HCl}$ buffer $(50 \mathrm{mM}, \mathrm{pH} 7.4)$. The suspension was homogenized with a Polytron homogenizer (Kinematica, Basel, Switzerland) under ice. Homogenates were centrifuged at $48,000 \times g\left(50 \mathrm{~min}, 4^{\circ} \mathrm{C}\right)$ and washed twice in the same conditions to isolate the membrane fraction. Protein was quantified by the bicinchoninic acid method (Pierce). For competition experiments, membrane suspensions $(50 \mu \mathrm{g}$ of protein/ $\mathrm{ml})$ were incubated in $50 \mathrm{mM}$ Tris- $\mathrm{HCl}(\mathrm{pH} 7.4) 0.5 \mathrm{nM}$ of $\left[{ }^{3 \mathrm{H}}\right] \mathrm{WIN}-35428$ (Perkin-Elmer) and increasing concentrations of the indicated competing drugs (WIN-35428 or cocaine) in the presence or the absence of $100 \mathrm{nM}$, $10 \mu \mathrm{M}$ or $1 \mathrm{mM}$ of $\mathrm{ZnCl}_{2}$ during $2 \mathrm{~h}$ at RT. Nonspecific binding was determined in the presence of $100 \mu \mathrm{M}$ cocaine. In all cases, free and membrane-bound radioligand were separated by rapid filtration through Whatman (Clifton, NJ) GF/B filters, pre-soaked in 0.05\% polyethyleneimine by using a Brandel R48 filtering manifold (Brandel Inc., Gaithersburg, MD). The filters were washed twice with $5 \mathrm{ml}$ of cold buffer and transferred to scintillation vials. Beckman Ready Safe scintillation cocktail $(3.0 \mathrm{ml})$ was added, and the vials were counted the next day with a Beckman 6000 liquid scintillation counter (Beckman Coulter Instruments, Fullerton, CA) at $50 \%$ efficiency.

\section{In vitro autoradiography using $\left[{ }^{3} \mathrm{H}\right] \mathrm{WIN}-35,428$}

Brain tissue from WT and ZnT3 KO mice was dissected, flash frozen in isopentane, and stored at $-80^{\circ} \mathrm{C}$ until sectioning. Tissue was sliced on a cryostat at $16 \mu \mathrm{m}$ and thaw mounted on positively charged glass slides and stored at $-20^{\circ} \mathrm{C}$ until autoradiography. Incubation Buffer consisted of $50 \mathrm{mM}$ Tris- $\mathrm{HCl}(7.4 \mathrm{pH})$ and $100 \mathrm{mM} \mathrm{NaCl}$ in deionized water. $\left[{ }^{3} \mathrm{H}\right] \mathrm{WIN}$ 35,428 Total binding buffer (S.A. $82.9 \mathrm{Ci} / \mathrm{mmol}$, Conc. $1 \mathrm{mCi} / \mathrm{ml}$ ) was made in incubation buffer at a concentration of $10 \mathrm{nM} . \mathrm{ZnCl}_{2}$ binding buffer was made using the Total binding buffer stock and adding $\mathrm{ZnCl}_{2}$ for a concentration of $10 \mu \mathrm{M}$. Slides were pre-incubated in ice-cold incubation buffer for $20 \mathrm{~min}$ then transferred to respective radioactive incubation buffers (i.e. total or total $+\mathrm{ZnCl}_{2}$ ) for $120 \mathrm{~min}$ on ice. Slides were then washed $2 \times 1 \mathrm{~min}$ in ice-cold $50 \mathrm{mM}$ Tris- $\mathrm{HCl}(\mathrm{pH}=7.4)$ then dipped ( $30 \mathrm{~s})$ in ice-cold deionized water. Slides were dried under stream of cool air and placed on BAS-IP TR 2025 E Tritium Screen (GE Healthcare) for 5 days and imaged using a phosphor imager (Typhoon FLA 7000; GE Healthcare). Sections were analyzed using Multigauge software (Fujifilm, Japan).

\section{In vivo fast scan cyclic voltammetry (FSCV)}

FSCV procedures follow those of recently published work from our laboratory in anesthetized mice using electrical stimulation [43]. Briefly, glass sealed $100 \mu \mathrm{m}$ carbon-fiber microelectrodes were pre-calibrated with known concentrations of dopamine and changes in $\mathrm{pH}$ to allow for a principal component analysis (PCA) of the raw data using HDCV (UNC, Chapel Hill, NC). Dopamine was identified by cyclic voltammogram using a voltage scan from -0.4 to $1.3 \mathrm{~V}$ at $400 \mathrm{~V} / \mathrm{s}$. During the experiment an external stimulus was applied using the tungsten electrode every $5 \mathrm{~min}$ comprised of 24 pulses $4 \mathrm{~ms}$ in width at $60 \mathrm{~Hz}$ and $180 \mu \mathrm{A}$ while the working electrode was implanted in the striatum (AP: $+1.5 \mathrm{~mm}$; $\mathrm{ML}$ : $\pm 1.0 \mathrm{~mm}$; DV: -3.2 to $-3.7 \mathrm{~mm}$ from bregma). After PCA data were analyzed to determine the $D A_{\text {Max }}$ and DA clearance rate using a custom macro written in Igor Carbon Pro which identified peaks greater than $3 \times$ root mean square noise and fit to Eq. 1 where $D_{A_{M a x}}$ represents the peak DA concentration measured, $k$ is the rate constant, and $t$ is time [43].

$\mathrm{DA}(\mathrm{t})=\mathrm{DA}_{\mathrm{Max}} e^{-k\left(t-t_{0}\right)}$

\section{Cocaine locomotor sensitization}

Each session during the development phase was $30 \mathrm{~min}$, and mice were only exposed to one session per day with locomotor activity quantified as distance traveled $(\mathrm{cm})$. All injections were administered (i.p.). Mice were first habituated to the locomotor activity chambers (Opto-varimex ATM3, Columbus Instruments). On the next two sessions, mice were injected with saline and placed in the chambers. On the following five sessions, separate groups were injected with either saline or cocaine $(10 \mathrm{mg} / \mathrm{kg})$ in a counterbalanced design. Mice were then allowed 7 days of withdrawal in the colony room and then returned to the behavior room for testing expression of sensitization. Briefly, all mice were allowed access to the activity chambers for $60 \mathrm{~min}$ followed by increasing doses of cocaine (saline, 5, 10, $20 \mathrm{mg} / \mathrm{kg}$ ) every $60 \mathrm{~min}$. Data collection was paused but chambers were not cleaned in-between cocaine dosing, each mouse was picked up, injected, and placed back in chamber to continue data collection.

\section{Cocaine conditioned place preference (CPP)}

The task consisted of ten sessions, one per day, in chambers with two visually distinct sides, one with clear walls and white floor and one with checkered walls and black floor. The sides were divided by a door with and without access to the other side. Locomotor activity was measured by way of time spent in each chamber as well as total distance traveled (Optovarimex ATM3, Columbus Instruments). In the first session, the mice could explore both sides of a conditioning box for $15 \mathrm{~min}$ to determine inherent side preference, designated as the Pre-Test. Using this data, the cocainepaired side was pseudo-randomized so that mice with a preference for one side $(>60 \%)$ were cocaine-paired on the other, non-preferred side. Mice with no side preference were cocaine-paired in a counterbalanced fashion. Separate groups of mice were conditioned with either a 5,10 or $20 \mathrm{mg} / \mathrm{kg}$ dose of cocaine. In an alternating fashion for 8 days, mice were injected (i.p.) with either saline or cocaine and placed in the predetermined drug/ no drug side of the chamber for $30 \mathrm{~min}$. The mice had no physical access to the other side but were still able to see through the clear divider wall. Each mouse had a total of 4 saline-paired days and 4 cocaine-paired days. The last session was the same as the first and designated the Test session. Time spent in the cocaine-paired chamber during the Pre-Test session (prior to conditioning) was subtracted from time spent in the cocainepaired chamber during the Test session and expressed as the Preference score.

\section{Mouse intravenous cocaine self-administration}

Mice were implanted with jugular vein catheters under ketamine/xylazine anesthesia and using aseptic surgical techniques. A $6.0 \mathrm{~cm}$ length 
MicroRenathane (ID 0.012", OD 0.025"; Braintree Scientific Inc., Braintree, MA, USA) catheter was inserted $1.2 \mathrm{~cm}$ into the right jugular vein and anchored to a 24-gauge steel cannula (Plastics One, Roanoke, VA, USA) that was bent at a $100^{\circ}$ angle and mounted to the skull with cyanoacrylate glue and dental acrylic. A $2.5 \mathrm{~cm}$ extension of flexible tubing was connected to the distal end of the cannula. The mice were allowed 5-7 days for recovery, during which time $0.05 \mathrm{ml}$ of a $0.9 \%$ saline solution containing $20 \mathrm{IU} / \mathrm{ml}$ heparin and $0.33 \mathrm{mg} / \mathrm{ml}$ gentamycin was infused daily through the catheter to prevent catheter clotting and infection. Thereafter, $0.05 \mathrm{ml}$ of $0.9 \%$ saline solution containing $20 \mathrm{IU} / \mathrm{ml}$ heparin was infused immediately prior to and immediately following each daily SA session. When needed, i.v. brevital (a barbiturate) was used to test catheter patency between the SA sessions. During cocaine SA sessions, the flexible tubing extension was connected to a perfusion pump (Med Associates, Fairfax, VT) via a PE50 tubing connector. After daily SA sessions, the free end of the cannula guide was always kept sealed.

Operant test chambers (Med Associates, Fairfax, VT) contained two levers (active and inactive) located $2.5 \mathrm{~cm}$ above the floor as well as a cue light above each lever. A house light mounted on the opposite side of the chamber signaled the start of each $3 \mathrm{~h}$ session and remained illuminated until the session ended. For SA sessions, a liquid swivel mounted on a balance arm above the chamber allowed for i.v. drug delivery in freely moving mice. Depression of the active lever resulted in the activation of an infusion pump; depression of the inactive lever was recorded but had no scheduled consequences. Each infusion was paired with two discrete cues: illumination of the cue light above the active lever, and a cue tone that lasted for the duration of the infusion. Experimental events were controlled by a PC programmed in Medstate Notation and connected to a Med Associates interface.

After recovery from surgery, mice were placed into operant chambers and allowed to lever press for i.v. cocaine SA under a fixed-ratio 1 reinforcement schedule (i.e., each lever press leads to one cocaine infusion) for $3 \mathrm{~h}$ daily. Each cocaine infusion lasted $4.2 \mathrm{~s}$, during which additional active lever responses were recorded but had no consequences (i.e., non-reinforced active lever response). Mice were trained initially for a high unit dose of cocaine (1 mg/kg/infusion) to potentiate acquisition of SA until stable SA was achieved, which was defined as earning at least 20 infusions per $3 \mathrm{~h}$ session and an active/inactive lever press ratio exceeding $2: 1$. Then the mice were switched to a multiple-dose schedule to observe the dose-dependent cocaine SA according to a descending cocaine dose sequence from the initial dose of $1 \mathrm{mg} / \mathrm{kg} /$ infusion (sessions 1-13) to $0.5 \mathrm{mg} / \mathrm{kg} / \mathrm{infusion}$ (sessions 14-20), $0.25 \mathrm{mg} / \mathrm{kg} /$ infusion (sessions $21-23$ ), $0.125 \mathrm{mg} / \mathrm{kg} /$ infusion (sessions 24-27), and $0.0625 \mathrm{mg} / \mathrm{kg} /$ infusion (sessions 28-29). Mice that did not reach stability criteria, lost catheter patency or showed excessive high-level inactive lever responding ( $>100$ presses per session) were excluded from further experimentation. To prevent cocaine overdose, maximally allowed cocaine infusions were 50 (0.1 and $0.5 \mathrm{mg} / \mathrm{kg} /$ infusion), 100 ( $0.25 \mathrm{mg} / \mathrm{kg} /$ infusion), 200 ( $0.125 \mathrm{mg} / \mathrm{kg} /$ infusion), or $400(0.0625 \mathrm{mg} / \mathrm{kg} /$ infusion $)$, respectively during each $3-\mathrm{h}$ session. The number of cocaine infusions earned, and active and inactive lever responses were recorded for each session. The last 2-3 days of cocaine SA data at each dose were averaged and used to compare dose-response performance between WT and KO mice.

After the completion of the above cocaine dose-response experiment, the animals were switched to cocaine SA under PR reinforcement schedule. During PR conditions, the work requirement (lever presses) needed to receive a cocaine infusion was raised progressively within each test session according to the following PR series: 1, 2, 4, 6, 9, 12, 15, 20, 25, $32,40,50,62,77,95,118,145,178,219,268,328,402,492$, and 603 until the breakpoint was reached. The breakpoint was defined as the maximal workload (i.e., number of lever presses) completed for the last cocaine infusion prior to a 1-h period during which no infusions were obtained by the animal. Animals were tested for cocaine SA under PR reinforcement at three doses (starting at 0.25 , then 1 and then $0.5 \mathrm{mg} / \mathrm{kg} /$ infusion) from days 30 to 38 .

After the completion of the PR experiments, the same groups of animals continued for cocaine extinction and reinstatement tests. During extinction, syringe pumps were turned off and the cocaine-associated cue light and tone were unavailable. Thus, lever pressing was recorded but had no scheduled consequences. Extinction training continued for about 20 days until the extinction criteria were met (i.e., lever responding $<20 \%$ of the SA baseline) for at least 3 sessions. Mice then received a $10 \mathrm{mg} / \mathrm{kg}$ i.p cocaine injection to evoke reinstatement of drug-seeking behavior. During reinstatement testing, active lever presses lead to re-exposure to the cue light and tone previously paired with cocaine infusions, but not to actual cocaine infusions. Active and inactive lever responses were recorded for each extinction and reinstatement session. Lever pressing behavior during the cocaine-primed session was compared to the average lever pressies during the last 3 days of extinction.

\section{Custom diets}

Diets were formulated by Research Diets, Inc via use of AIN-93M mature rodent diet. The diets were compositionally identical, but one diet had an adequate amount of $\mathrm{Zn}^{2+}(30 \mathrm{ppm})$ and the other diet had a deficient amount of $\mathrm{Zn}^{2+}(5 \mathrm{ppm}) . \mathrm{Zn}^{2+}$ concentration in each diet was confirmed in-house via random sampling of chow pellets and TXRF (S2 Picofox, Bruker, Billerica, MA).

\section{Body weight and food intake measurements}

C56BL/6J mice arrived at the NIDA mouse colony and were allowed one week of environmental acclimation with regular chow and water available ad lib. After the acclimation period, mice were given a diet containing either $30 \mathrm{ppm} \mathrm{Zn}^{2+}$ or $5 \mathrm{ppm} \mathrm{Zn}^{2+}$ for a minimum of 35 days prior to any behavioral manipulations. Mice stayed on the diet until the completion of the experiment. Mice were individually housed and weighed three times per week along with food weight to track the amount of food consumed.

\section{Immunohistochemistry}

Coronal sections were sliced on a cryostat $(30 \mu \mathrm{m})$, collected in six-well plates with PBS, and stored at $4{ }^{\circ} \mathrm{C}$ until use. Sections were transferred to 12-well plates and permeabilized in washing buffer (PBS + Triton X-100 $0.1 \%$ ) for $10 \mathrm{~min}$ at room temperature on a shaker. Tissue was blocked in blocking buffer (BSA 3\% + PBS + Triton X-100 0.1\%) for 60 min at RT on shaker. Tissue was incubated overnight in primary ZnT3 antibody (1:500) (anti-rabbit, \#197 003, Synaptic Systems, Goettingen, Germany) at $4{ }^{\circ} \mathrm{C}$. Tissue was washed with washing buffer $3 \times 10 \mathrm{~min}$ at RT then incubated in secondary antibody (Alexa 488-Rabbit \#A1134, Thermo Fisher (1:400), Topro (1:1200), and DAPI $(1: 600)$ for $2 \mathrm{~h}$ at RT in the dark. Tissue was washed with washing buffer $3 \times 10 \mathrm{~min}$, transferred to dish with PBS, mounted on positively charged glass slides, and coverslipped with aqueous mounting medium ( $90 \%$ glycerol $+30 \mathrm{mM}$ Tris- $\mathrm{HCl}, \mathrm{pH} 8.0$ ) and imaged using confocal microscopy.

\section{Statistics}

Sample sizes were estimated based on prior experience with the specific assays/experiments and expected effect sizes. Mice (with the exception of ZnT3 KO) were randomly selected from littermates into experimental groups. Experiments were performed unblinded. Depending on experiment, we used linear regression, unpaired t-tests, one sample nonparametric (Wilcoxon) tests, one or two-way ANOVA or a mixed effects model (to account for missing data) taking RM into account when appropriate. Significant main or interaction effects were followed by Holm-Sidak pairwise comparisons. All statistical tests were evaluated at the $p \leq 0.05$ level. Estimation statistics were used for experiments with low sample size (e.g., $n<5)$ or with data that were not normally distributed (www.estimationstats.com) [44].

\section{RESULTS}

\section{Striatal $\mathrm{Zn}^{2+}$ is low in human cocaine users and correlates with cocaine intake}

The highest DAT density in the brain is found in the striatum [28], a region heavily implicated in cocaine addiction [45-48]. Human drug users are characterized by nutritional deficiencies and dysregulated blood and hair $\mathrm{Zn}^{2+}$ content [33-38] but whether they show deficits in striatal $\mathrm{Zn}^{2+}$ is unknown. To assess this, we performed elemental profiling using TXRF in postmortem striatal tissue derived from humans whose primary cause of death was attributed to cocaine abuse $(n=19)$ or matched controls $(n=20)$ (Fig. 1A). Cocaine users and controls did not differ in age (Fig. 1B) or brain $\mathrm{pH}$ content (Fig. 1C). We found that cocaine users had significantly lower (unpaired $t$-test, $t=2.87 ; p=0.006$ ) striatal $\mathrm{Zn}^{2+}$ levels compared to controls (Fig. 1D). This difference was selective to $\mathrm{Zn}^{2+}$ as we did not detect significant differences in other elements (Fig. S1). Striatal $\mathrm{Zn}^{2+}$ levels in these subjects 
A

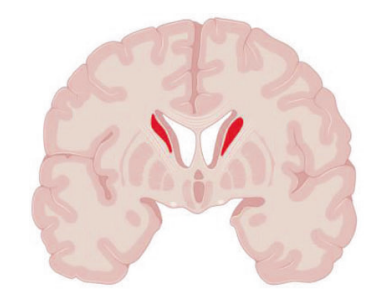

D

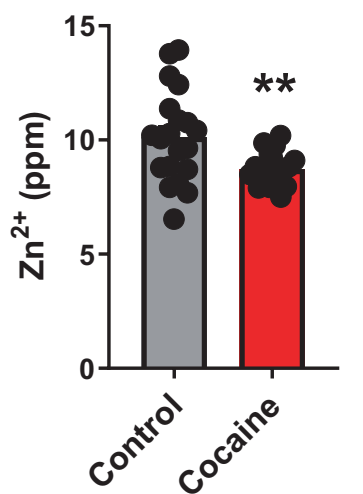

B

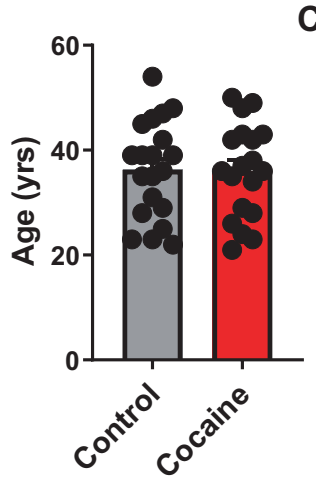

C

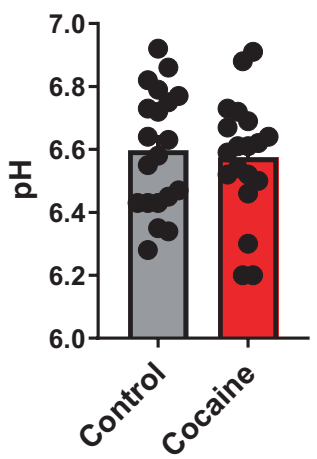

E

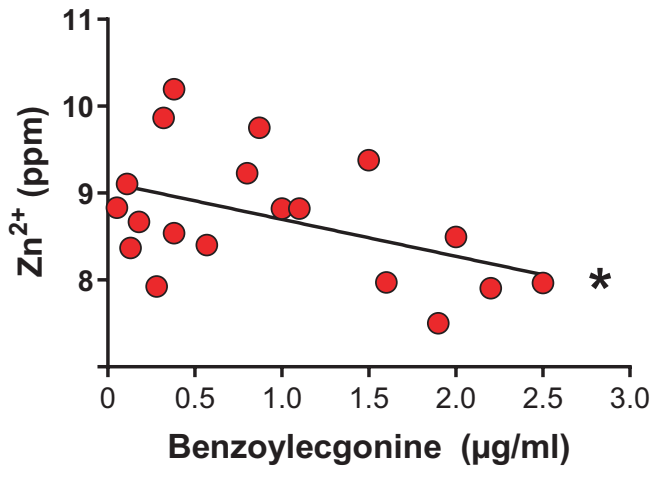

Fig. 1 Striatal $\mathrm{Zn}^{2+}$ is low in human cocaine users and correlates with cocaine intake. A Schematic showing sampled region (caudate) from postmortem human brain samples. B Cocaine users and control subjects did not differ in age or (C) in tissue pH. (D) Cocaine users showed significantly lower striatal $\mathrm{Zn}^{2+}$ levels compared to control subjects. (E) Striatal $\mathrm{Zn}^{2+}$ levels in cocaine users significantly correlated with plasma benzoylecgonine levels (ppm - parts per million). ${ }^{* *} p \leq 0.01,{ }^{*} p \leq 0.05$. All data expressed as Mean \pm SEM.

significantly and negatively correlated (linear regression; $F(1,17)$ $=4.5 ; p=0.04$ ) with plasma concentrations of benzoylecgonine, (Fig. 1E) a stable cocaine metabolite indicative of recent cocaine use [49].

\section{Cocaine increases synaptic $\mathrm{Zn}^{2+}$ release and uptake in the striatum}

To obtain mechanistic insights in the relationship between cocaine exposure and striatal $\mathrm{Zn}^{2+}$ levels, we examined striatal $\mathrm{Zn}^{2+}$ content in mice exposed to cocaine. Unlike TXRF, synchrotron X-ray fluorescence microspectroscopy ( $\mu$ SXRF) allows visualization and quantification of $\mathrm{Zn}^{2+}$ in brain slices [50,51]. We first verified that the distribution of $\mathrm{Zn}^{2+}$, as detected by $\mu$ SXRF in the hippocampus, where synaptic $\mathrm{Zn}^{2+}$ levels are high, coincided with distributions of ZnT3 immunolabeling and histochemically reactive synaptic $\mathrm{Zn}^{2+}$ [52] (Fig. S2). We then performed $\mu$ SXRF in striatal sections from mice exposed to daily cocaine injections (10 $\mathrm{mg} / \mathrm{kg}$, intraperitoneal (IP), 4 days, $n=4$ ) and euthanized $24 \mathrm{~h}$ later. We found that cocaine-exposed mice had significantly greater total $\mathrm{Zn}^{2+}$ levels in the $\mathrm{CPu}$ [unpaired mean difference: Veh vs. Coc $=111 ;(95.0 \% \mathrm{Cl} 66.4,139), p=0.003]$ and in the NAC [unpaired mean difference: Veh vs. $\mathrm{Coc}=65.3$; $(95.0 \% \mathrm{Cl} 47.4$, 98.2); $p<0.001$ ] compared to vehicle-injected mice $(n=5)$ (Fig. $2 \mathrm{~A}, \mathrm{~B})$. There was no significant difference in Ctx [unpaired mean difference: Veh vs. Coc $=77.8$; $(95.0 \% \mathrm{Cl} 85.1,141) ; p=0.09$ ].

$\mathrm{ZnT3}$ KO mice lack the ability to package $\mathrm{Zn}^{2+}$ into synaptic vesicles and by extension cannot release synaptic $\mathrm{Zn}^{2+}[10]$. We hypothesized that the increase in cocaine-induced striatal $\mathrm{Zn}^{2+}$ we observed in mice was mediated via ZnT3. To assess this, we first confirmed that $\mathrm{ZnT3} \mathrm{KO}$ mice lack histochemically reactive [52] synaptic $\mathrm{Zn}^{2+}$. In agreement with prior findings [53], we found that synaptic $\mathrm{Zn}^{2+}$ was enriched in discrete areas including medial cortical regions, dorsomedial $\mathrm{CPu}$, and medial NAc in WT mice (Fig. 2C) and as expected, ZnT3 KO mice completely lacked synaptic $\mathrm{Zn}^{2+}$ (Fig. 2D). We then exposed WT and $\mathrm{ZnT3}$ KO mice to daily vehicle ( $n=6 \mathrm{WT}, n=9 \mathrm{KO})$, a single $(20 \mathrm{mg} / \mathrm{kg} / \mathrm{day}, \mathrm{IP})$ cocaine injection (SC) $(n=4 \mathrm{WT}, n=4 \mathrm{KO})$ or repeated cocaine (RC) $(20 \mathrm{mg} / \mathrm{kg} /$ day for 8 days, IP) ( $n=5 \mathrm{WT}, n=4 \mathrm{KO})$ injections and euthanized them $24 \mathrm{~h}$ later followed by dissection of medial frontal Ctx and striatum and assessment of $\mathrm{Zn}^{2+}$ using TXRF. Vehicle-treated ZnT3 KO mice had significantly lower $\mathrm{Zn}^{2+}$ than vehicle-treated WT mice in Ctx (Fig. S3), where ZnT3 expression and synaptic $\mathrm{Zn}^{2+}$ pools are high (Fig. $2 \mathrm{C}$ ). In contrast, vehicletreated WT and ZnT3 KO mice did not differ in striatal $\mathrm{Zn}^{2+}$, as synaptic $\mathrm{Zn}^{2+}$ levels in this region are low (Fig. 2E, F) and differences under these basal circumstances were below the detection limit of TXRF (Fig. 2E). WT mice exposed to a SC injection did not differ in striatal $\mathrm{Zn}^{2+}$ compared to vehicle-treated WT mice [shared control (WT VEH) comparison; unpaired mean difference: vehicle vs. $\mathrm{SC}=1.52$; $(95.0 \% \mathrm{Cl}-0.31,2.84), \mathrm{p}=0.07$ ] (Fig. 2E, F). In agreement with results from our $\mu S X R F$ experiments (Fig. $2 A, B$ ), WT mice exposed to RC injections had significantly greater striatal $\mathrm{Zn}^{2+}$ content than vehicle-treated WT mice [unpaired mean difference: vehicle vs. $\mathrm{RC}=3.41 ;(95.0 \% \mathrm{Cl} 0.76,6.87), p=0.03$ ] (Fig. 2E, F). In contrast, cocaine exposure did not lead to any differences in striatal $\mathrm{Zn}^{2+}$ in $\mathrm{ZnT3}$ KO mice (Fig. 2E, F).

As a trace element, $\mathrm{Zn}^{2+}$ is challenging to study in vivo. Consequently, in vivo brain $\mathrm{Zn}^{2+}$ kinetics have not been previously described. However, ex vivo studies using radioactive ${ }^{65} \mathrm{ZnCl}_{2}$ have shown that $\mathrm{Zn}^{2+}$ has unique brain kinetics, uptake, and biodistribution profiles. Specifically, systemic injection of ${ }^{65} \mathrm{ZnCl}_{2}$ takes about 6 days to reach maximal brain uptake [54]. 

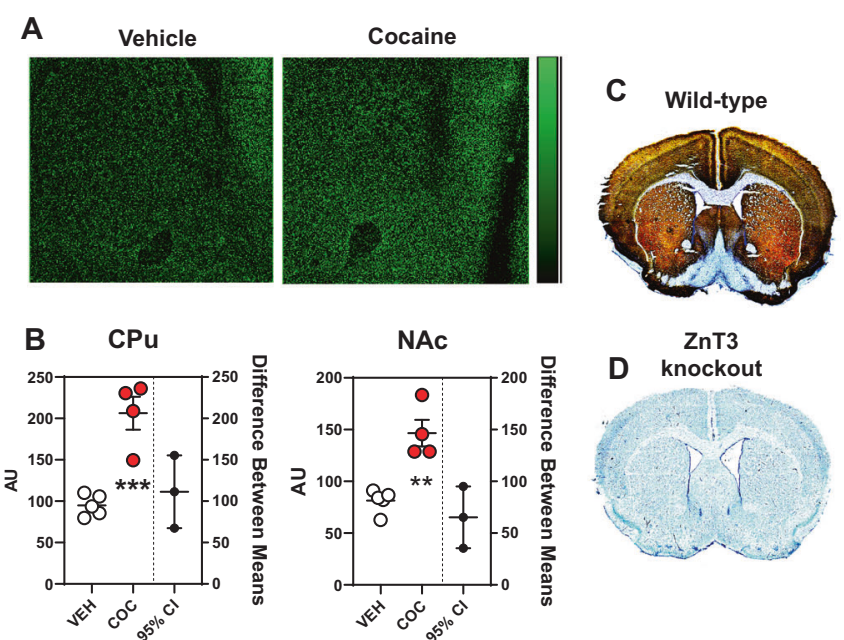

$95 \% \mathrm{Cl}$
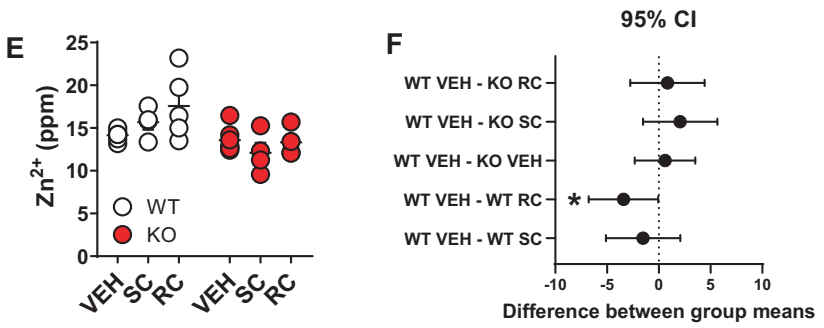

G

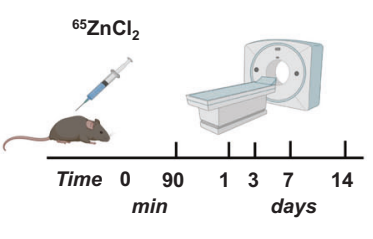

H
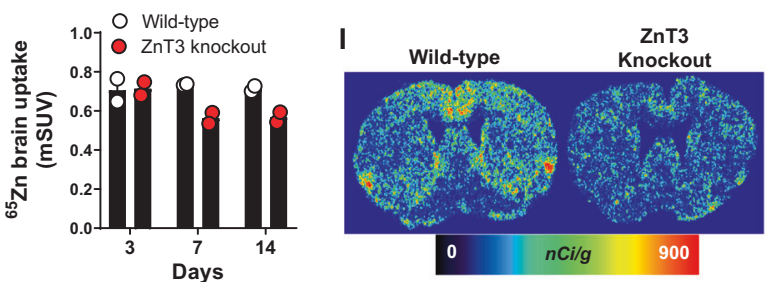

J Cocaine $>$ Vehicle (hot-orange) Cocaine $<$ Vehicle (cool - blue)

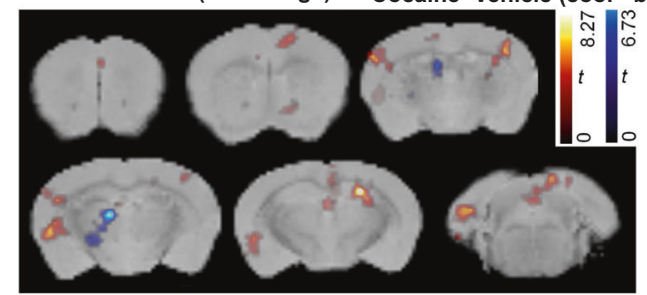

Fig. 2 Cocaine increases synaptic $\mathrm{Zn}^{2+}$ release and uptake in the striatum. A Representative synchrotron $\mathrm{X}$-ray fluorescence microspectroscopy ( $\mu$ SXRF) $\mathrm{Zn}^{2+}$ maps from vehicle- or cocaine-treated mice. B Cocaine-treated mice had significantly greater $\mathrm{Zn}^{2+}$ (AUarbitrary units) than vehicle-treated mice in caudate putamen (CPu) and nucleus accumbens (NAc). C Representative Timm- and cresyl violetco-stained sections from a wild-type (WT) and D a ZnT3 knockout (KO) mouse. E Zn ${ }^{2+}$ content measured using TXRF in wild-type and ZnT3 knockout mice exposed to vehicle (VEH), a single cocaine injection (SC) or repeated cocaine injections (RC) injections. F Wild-type mice exposed to RC had significantly greater $\mathrm{Zn}^{2+}$ levels compared to VEH-treated WT mice. G PET experimental timeline and representative horizontal ${ }^{65} \mathrm{Zn}$ PET/CT images from wild-type and $\mathrm{ZnT3}$ knockout mice scanned at 14 days after ${ }^{65} \mathrm{ZnCl}_{2}$ administration. $\mathrm{H}^{65} \mathrm{ZnCl}_{2}$ brain uptake expressed as mean standard uptake value (mSUV) in wild-type and knockout mice scanned at 3, 7 and 14 days after injection. I Representative ${ }^{65} \mathrm{ZnCl}_{2}$ autoradiograms from wild-type and $\mathrm{ZnT3}$ knockout mice scanned using PET at day 15 after ${ }^{65} \mathrm{ZnCl} 2$ administration and then euthanized for postmortem verification. J Statistical contrasts from voxel-wise statistical parametric mapping analyses from vehicleor cocaine-treated mice exposed to ${ }^{65} \mathrm{ZnCl}_{2}$ PET imaging. ppm parts per million. ${ }^{*} p \leq 0.05,{ }^{* *} p \leq 0.01,{ }^{* * *} p \leq 0.001$. All data expressed as Mean \pm SEM.

Similarly, another study estimated $\mathrm{Zn}^{2+}$ turnover in the brain to be a slow process, taking $\sim 7$ days [55]. Importantly, the ex vivo brain distribution of systemically administered ${ }^{65} \mathrm{ZnCl}_{2}$ is dependent on neuronal activity [56] and overlaps with both distribution of ZnT3 protein and histochemically reactive $\mathrm{Zn}^{2+}$ [54], suggesting that the majority of $\mathrm{Zn}^{2+}$ uptake to the brain is in the form of synaptic $\mathrm{Zn}^{2+}$. In agreement with this, studies have shown that ${ }^{65} \mathrm{ZnCl}_{2}$ is transported throughout the brain in a trans-synaptic manner [57]. Finally, like synaptic $\mathrm{Zn}^{2+}[31],{ }^{65} \mathrm{ZnCl}_{2}$ brain uptake is dependent on dietary $\mathrm{Zn}^{2+}$ intake [58]. Collectively, these studies indicate that ${ }^{65} \mathrm{ZnCl}_{2}$ brain uptake can be used as a measure of synaptic $\mathrm{Zn}^{2+}$ turnover/metabolism. Interestingly, ${ }^{65} \mathrm{Zn}$ produces annihilation photons at $511 \mathrm{keV}$ at a low ( 3\%) abundance and has a physical half-life of $\sim 244$ days. We reasoned that these physical characteristics would be sufficient for noninvasive and longitudinal measurements of ${ }^{65} \mathrm{ZnCl}_{2}$ uptake and kinetics using positron emission tomography (PET) and thus could provide in vivo assessments of brain $\mathrm{Zn}^{2+}$ turnover/metabolism. To confirm, WT $(n=2)$ and ZnT3 KO $(n=2)$ mice were injected intravenously (IV) with $2 \mu \mathrm{Ci} / \mathrm{g}{ }^{65} \mathrm{ZnCl}_{2}$ and scanned using PET. Owing to the slow kinetics and long biological and physical halflives of $\mathrm{Zn}^{2+}$ [54], mice were scanned longitudinally at different days after ${ }^{65} \mathrm{ZnCl}_{2}$ injection (Fig. $2 \mathrm{G}$ ). ${ }^{65} \mathrm{Zn}$ showed rapid brain uptake, exhibited slow brain clearance, and was detected in the brain up to 14 days after injection (Fig. 2G, H and Fig. S4). ZnT3 KO mice had lower brain uptake of ${ }^{65} \mathrm{ZnCl}_{2}$ at 7 - and 14 days post injection compared to WT mice (Fig. 2H). This was confirmed ex vivo using autoradiography, which showed that ${ }^{65} \mathrm{Zn}$ brain distribution overlapped with distribution of synaptic $\mathrm{Zn}^{2+}$ and ZnT3 protein in WT mice (Fig. $2 \mathrm{l}$ and Fig. S5). Notably, whereas $\mathrm{ZnT3} \mathrm{KO}$ mice did show some minimal ${ }^{65} \mathrm{ZnCl}_{2}$ uptake, perhaps representing nonspecific uptake or a result of other zinc transporters expressed in the brain [59], the distribution of ${ }^{65} \mathrm{ZnCl}_{2}$ uptake in $\mathrm{KO}$ mice was largely absent from $\mathrm{ZnT3}$-rich regions, indicating that it did not represent the synaptic $\mathrm{Zn}^{2+}$ pool. Next, to examine effects of cocaine on ${ }^{65} \mathrm{ZnCl}_{2}$ brain uptake, we injected mice with ${ }^{65} \mathrm{ZnCl}_{2}$ as above followed by daily vehicle $(n=4)$ or cocaine $(n=3)$ injections $(20 \mathrm{mg} / \mathrm{kg} /$ day, IP, 8 days $)$ and performed PET. Compared to vehicle, cocaine significantly (oneway anova, treatment main effect, $\mathrm{t}$ contrast $(1,4)=2.13 ; p=$ 0.049 ) increased uptake of ${ }^{65} \mathrm{ZnCl}_{2}$ in brain regions with high $\mathrm{ZnT3}$ and synaptic $\mathrm{Zn}^{2+}$ levels, including the prelimbic, cingulate, sensory cortices, NAc, hippocampus, and amygdala but decreased it in areas of low $\mathrm{ZnT3}$ and synaptic $\mathrm{Zn}^{2+}$ levels like thalamus (Fig. 2J).

\section{Synaptic $\mathrm{Zn}^{2+}$ release increases the in vivo potency of cocaine} on striatal DA neurotransmission

In vitro studies indicate that $\mathrm{Zn}^{2+}$ binds to the DAT and causes (i) DA reuptake inhibition and (ii) increased cocaine-DAT binding $[18,21,22,60,61]$. We reproduced these findings using mouse striatal membranes ( $n=6$ mice/pooled) whereby a physiologically 
A
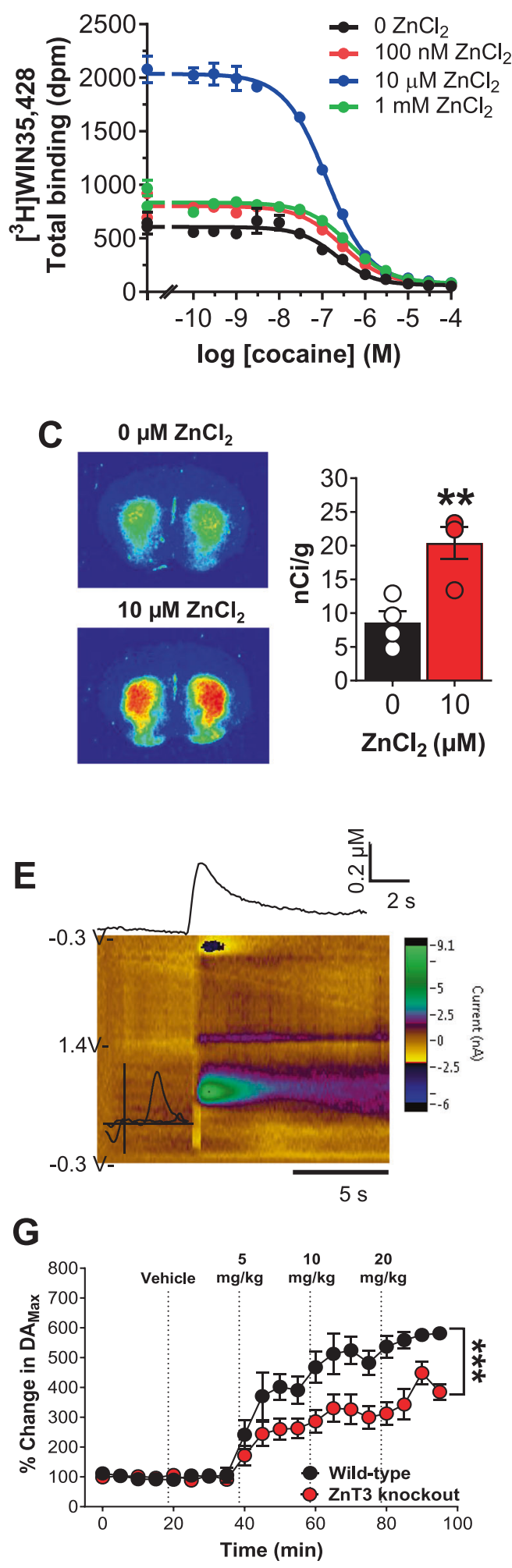

achievable concentration $(10 \mu \mathrm{M})$ of $\mathrm{Zn}^{2+}$ [1] significantly increased [unpaired mean difference: 0 vs. $10 \mu \mathrm{M}=-0.627$; $(95.0 \% \mathrm{Cl}-0.86,-0.41), p<0.001]$ cocaine binding and affinity to the DAT (Fig. 3A, B, Fig. S6). A higher, supraphysiological concentration (1 mM), decreased [unpaired mean difference: 0 vs. $1000 \mu \mathrm{M}=2.51$; $(95.0 \% \mathrm{Cl} 0.88,3.43), p=0.06$ ] cocaine affinity
B
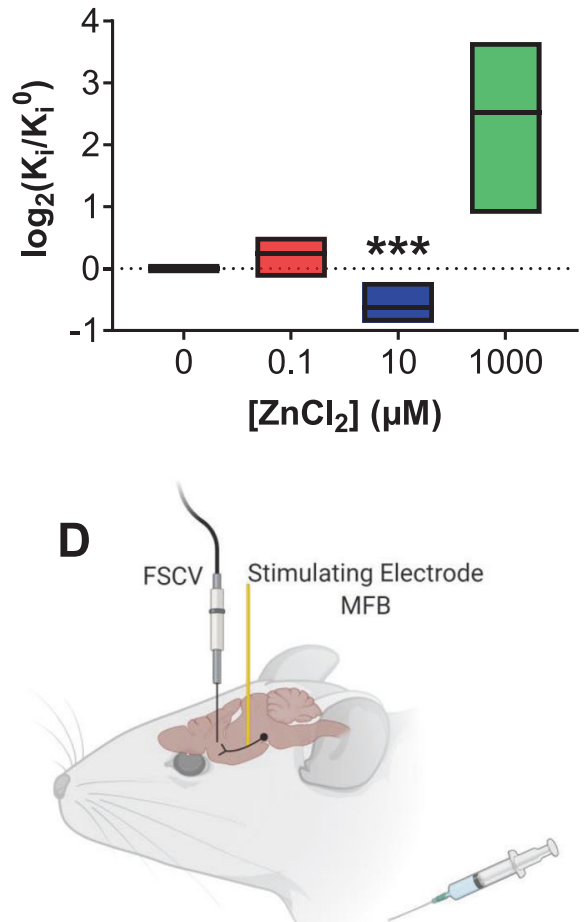

Cocaine
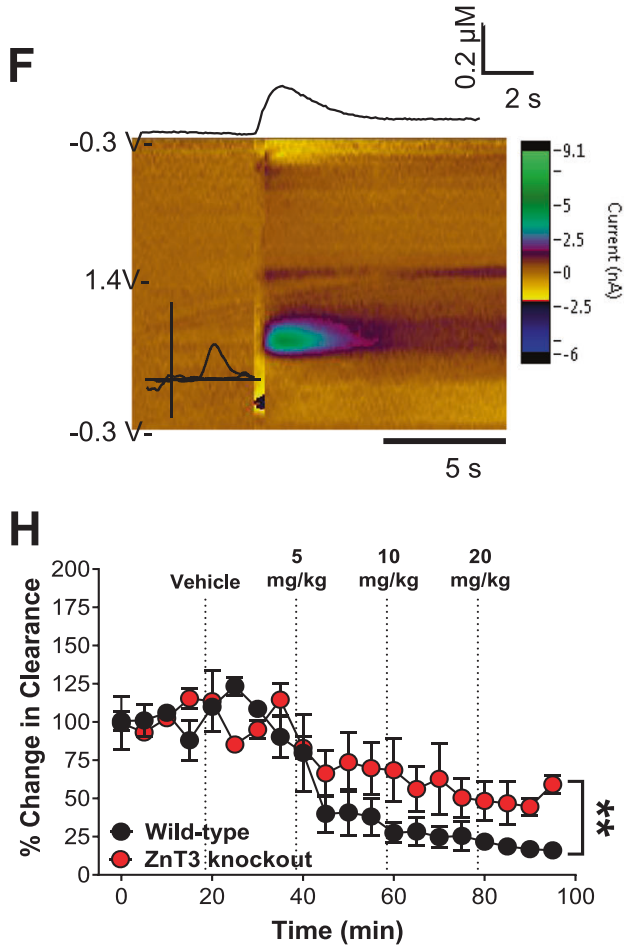

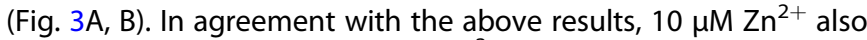
significantly increased binding of $\left[{ }^{3} \mathrm{H}\right] \mathrm{WIN}-35,428$ to the DAT in tissue sections ( $n=4$ mice) (unpaired $t$-test, $t=4.03 ; p=0.007$ ) (Fig. 3C).

To assess cocaine's in vivo effects at the DAT as a function of synaptic $\mathrm{Zn}^{2+}$, we performed in vivo FSCV in the striatum of WT ( $n$ 
Fig. 3 Synaptic $\mathrm{Zn}^{2+}$ release increases the in vivo potency of cocaine on striatal DA neurotransmission. A Competition binding curves of cocaine and $\mathrm{ZnCl}_{2}$ against $\left[{ }^{3} \mathrm{H}\right] \mathrm{WIN}-35,428$ in mouse striatal tissue. B $10 \mu \mathrm{M} \mathrm{ZnCl}_{2}$ significantly increased and $1 \mathrm{mM} \mathrm{ZnCl} 2$ decreased affinity of cocaine in mouse striatum (Ki ( \pm SD)) values in $\mathrm{nM}$; Cocaine: $0 \mu \mathrm{M} \mathrm{Zn,} \mathrm{63 \pm 39;} 0.1 \mu \mathrm{M} \mathrm{Zn,} \mathrm{77 \pm 57;10 \mu M} \mathrm{Zn,} 43 \pm 31 ; 1000 \mu \mathrm{M} Z \mathrm{n}, 611 \pm 843$ and WIN-35,428: $0 \mu \mathrm{M} Z n, 9 \pm 1.2 ; 0.1 \mu \mathrm{M} Z n, 9.2 \pm 0.8 ; 10 \mu \mathrm{M} Z n, 5.1 \pm 1.1 ; 1000 \mu \mathrm{M} Z n, 13.4 \pm 1.8)$. C Autoradiograms at the level of mouse striatum showing that $10 \mu \mathrm{M} \mathrm{ZnCl}$ significantly increased $\left[{ }^{3} \mathrm{H}\right] \mathrm{WIN}-35,428$ binding. D Experimental design of fast scan cyclic voltammetry (FSCV) experiment. E Representative FSCV color plots from wild-type and F ZnT3 knockout mice showing changes in electrically-evoked dopamine (DA) after a $10 \mathrm{mg} / \mathrm{kg} \mathrm{IP} \mathrm{cocaine} \mathrm{injection.} \mathrm{G} \mathrm{FSCV} \mathrm{time-course} \mathrm{plots} \mathrm{showing} \mathrm{significantly} \mathrm{lower} \mathrm{percent} \mathrm{change} \mathrm{in} \mathrm{electrically-evoked} \mathrm{DA}{ }_{\text {Max }}$ and $\mathbf{H}$ faster DA Clearance rate in ZnT3 knockout compared to wild-type mice as a function of vehicle or escalating IP cocaine injections. ${ }^{*} p \leq$ $0.05,{ }^{* *} p \leq 0.01,{ }^{* * *} p \leq 0.001$. All data expressed as Mean \pm SEM.

$=4)$ and ZnT3 KO $(n=4)$ mice. Electrical stimulation of the medial forebrain bundle was used to evoke DA release in the striatum followed by escalating cocaine injections $(5,10,20 \mathrm{mg} / \mathrm{kg}$, IP) (Fig. 3D). WT and ZnT3 KO mice did not differ in baseline DA release or clearance (Fig. S7). DA release: compared to vehicle, we found that 5,10 , and $20 \mathrm{mg} / \mathrm{kg}$ cocaine significantly increased electricallyevoked extracellular DA release in WT mice, but ZnT3 KO mice only showed a significant increase at $20 \mathrm{mg} / \mathrm{kg}$ cocaine (Fig. S7). ZnT3 KO mice also showed significantly lower electrically evoked extracellular DA release compared to WT mice (two-way RM anova; genotype $\times$ time interaction, $F(19,114)=5.46 ; p<0.001)$ (Fig. 3E, G). DA clearance: compared to Vehicle, 5, 10, and $20 \mathrm{mg} / \mathrm{kg}$ cocaine significantly decreased DA clearance in WT mice as compared to Vehicle, but ZnT3 KO mice only showed significantly lower DA clearance at $20 \mathrm{mg} / \mathrm{kg}$ cocaine (Fig. S7). ZnT3 KO mice showed significantly greater DA clearance in response to cocaine compared to WT mice (two-way RM anova; genotype $\times$ time interaction, $F(19,114)=2.35 p=0.0029)(F i g .3 F, H)$.

\section{Synaptic $\mathrm{Zn}^{2+}$ release potentiates cocaine locomotor sensitization, reward, seeking and is required for cocaine- induced increases in DAT}

We hypothesized that cocaine-induced synaptic $\mathrm{Zn}^{2+}$ release would modulate cocaine-related behavior. To examine this, we first tested ZnT3 KO mice for development and expression of cocaine-induced locomotor sensitization. WT $(n=15)$ and ZnT3 KO mice $(n=16)$ both developed locomotor sensitization to daily injections of cocaine $(10 \mathrm{mg} / \mathrm{kg} /$ day, IP, 5 days) (two-way RM anova with Holm-Sidak multiple comparisons, genotype $\times$ session interaction, $F(3,59)=7.07 ; p=0.004$ ) (Fig. 4A). However, ZnT3 KO mice $(n=16)$ showed significantly lower locomotor activity compared to cocaine-treated WT mice on Day $1(t=3.09 ; p=$ $0.01)$ and Day $5(t=3.22 ; p=0.009)$ of the procedure. As expected, WT mice injected with cocaine showed significantly greater locomotor activity than vehicle-treated WT $(n=16)$ mice on Day $1(t=5.54 ; p<0.001)$ and Day $5(t=8.71 ; p<0.001)$. KO mice injected with cocaine showed significantly greater locomotor activity than vehicle-treated KO $(n=16)$ mice on Day $5(t=5.68 ; p$ $<0.001)$ but not on Day $1(t=2.48 ; p=0.08)$. One week later, vehicle-treated and cocaine-treated mice were tested for expression of cocaine locomotor sensitization via exposure to escalating cocaine injections $(5,10$, and $20 \mathrm{mg} / \mathrm{kg}, \mathrm{IP})$. WT mice with prior cocaine exposure (cocaine-treated) $(n=9)$ showed significantly greater (2-way RM anova with Holm-Sidak multiple comparisons, genotype $\times$ time interaction, $F(79,1343)=1.85 ; p<0.001)$ expression of cocaine locomotor sensitization at 5 (66 $\mathrm{min} ; t=3.65 ; p=$ $0.02,69 \mathrm{~min} ; t=3.72 ; \mathrm{p}=0.01)$ and $10 \mathrm{mg} / \mathrm{kg}$ cocaine (123 min; $t$ $=5.24 ; p<0.001,126 \mathrm{~min} ; t=6.03 ; p<0.001,129 \mathrm{~min} ; t=5.19 ; p$ $<0.001,132 \mathrm{~min} ; \mathrm{t}=3.75 ; p=0.01,135 \mathrm{~min} ; t=3.54 ; p=0.03$ ) compared to vehicle-treated WT mice $(n=10)$ (Fig. 4B). In contrast, cocaine-treated KO mice $(n=10)$ did not show a significant increase in locomotor activity (two-way RM anova, genotype $\times$ time interaction, $F(79,1422)=0.9197 ; p=0.67)$ compared to vehicle-treated KO mice $(n=10)$ (Fig. 4C). Neither WT nor ZnT3 KO cocaine-treated mice differed from the corresponding vehicle-treated mice at a $20 \mathrm{mg} / \mathrm{kg}$ dose of cocaine (Fig. 4B, C).

Cocaine exposure increases DAT levels $[47,48,62]$ which is thought to serve as a compensatory adaptation to DAT blockade after RC exposure. We hypothesized that ZnT3 KO mice, which lack cocaine-induced $\mathrm{Zn}^{2+}$ release and expression of cocaineinduced locomotor sensitization, would be insensitive to cocaineinduced increases in striatal DAT. To test this, mice from the above sensitization experiments were euthanized $24 \mathrm{~h}$ after the last cocaine injection, the striatum was dissected, and DAT binding assays were performed using $\left[{ }^{3} \mathrm{H}\right] \mathrm{WIN}-35,428$ (three repetitions per curve, in triplicate) (one-way ANOVA: $F(3,8)=6.23 ; p=0.01$ ). Pairwise comparisons (Holm-Sidak) showed that vehicle-treated WT mice $(n=6)$ did not differ from vehicle- or cocaine-treated ZnT3 KO mice $(n=6)$ in $\left[{ }^{3} \mathrm{H}\right] \mathrm{WIN}-35,428$ binding (Fig. 4D). However, cocaine-treated WT mice $(n=6)$ showed a trend toward greater $\left[{ }^{3} \mathrm{H}\right] \mathrm{WIN}-35,428$ binding $(t=2.21 ; p=0.058)$ compared to vehicle-treated WT mice $(n=6)$ and significantly greater $\left[{ }^{3} \mathrm{H}\right] \mathrm{WIN}-$ 35,428 binding than both vehicle-treated $(n=6)(t=4.14 ; p=$ $0.009)$ and cocaine-treated KO mice $(n=6)(t=3.12 ; p=0.02)$.

Next, we tested whether synaptic $\mathrm{Zn}^{2+}$ release is involved in cocaine reward by assessing the extent to which ZnT3 KO mice develop cocaine CPP. As expected, we found that WT mice showed significant preference for a chamber paired with cocaine (one sample Wilcoxon (non-parametric) test with theoretical median set to 0$)$ at $5(n=8)(p=0.007 ; 95 \% \mathrm{Cl}: 41.3-336.1), 10$ $(n=9) \quad(p=0.003 ; 95 \% \mathrm{Cl}: 59.2-297.3)$, and $20(n=8)(p=0.01$; $95 \%$ Cl: -9.8 to 258.4$) \mathrm{mg} / \mathrm{kg}$. In contrast, ZnT3 KO mice did not show significant preference for the chamber paired with cocaine at any dose: $5 \mathrm{mg} / \mathrm{kg}(n=7)(p=0.21 ; 95 \% \mathrm{Cl}$ : -118.8 to 256.2$)$, $10 \mathrm{mg} / \mathrm{kg}(n=9)(p=0.07 ; 95 \% \mathrm{Cl}:-47.2$ to 208.5$)$ and $20 \mathrm{mg} / \mathrm{kg}$ $(n=7)(p=0.10 ; 95 \% \mathrm{Cl}:-140.6$ to 159.3$)$ (Fig. $4 \mathrm{E})$.

Finally, we examined whether synaptic $\mathrm{Zn}^{2+}$ is involved in intravenous cocaine SA. WT mice $(n=9)$ showed robust acquisition of cocaine SA (1 mg/kg/infusion for 13 days), as evidenced by significantly greater (Mixed effects anova with Holm-Sidak multiple comparisons); genotype $\times$ session interaction, $\mathrm{F}(12,190)=6.12 ; p<0.001)$ and sustained responding on the cocaine-reinforced active lever over the non-reinforced inactive lever on days 11 and 12 (session 11: $t=6.48$; $\mathrm{p}<$ 0.001 , session 12: $t=4.25 ; p=0.009$ ) (Fig. 4F). In contrast, ZnT3 KO mice $(n=9)$ failed to acquire cocaine SA at the $1 \mathrm{mg} / \mathrm{kg} /$ infusion dose (Fig. 4H) as they did not show any significant differences (two-way RM anova with Holm-Sidak multiple comparisons, genotype $\times$ session interaction, $F(12,192)=1.27$; $p=0.23$ ) in cocaine-reinforced vs. inactive lever pressing. All mice were then switched to a lower cocaine dose $(0.5 \mathrm{mg} / \mathrm{kg} /$ infusion for 7 days). WT mice $(n=7)$ immediately reached the maximum allowed number (50) of infusions (Fig. 4G) and showed significantly greater cocaine-reinforced presses (two-way RM anova with Holm-Sidak multiple comparisons, lever main effect, $F(1,12)=116.7 ; p<0.001)$ compared to inactive lever presses (session 1: $t=12.54 ; p<0.001$, session 2: $t=5.03 ; p=0.004$, session $3: t=7.91 ; p<0.001$, session $4: t=9.39 ; p<0.001$, session 5: $t=15.45 ; \mathrm{p}<0.001$, session $6: t=23.33 ; p<0.001$, session $7: t$ $=10.42 ; p<0.001)$. At the $0.5 \mathrm{mg} / \mathrm{kg} /$ infusion dose, $\mathrm{ZnT3} \mathrm{KO}$ 

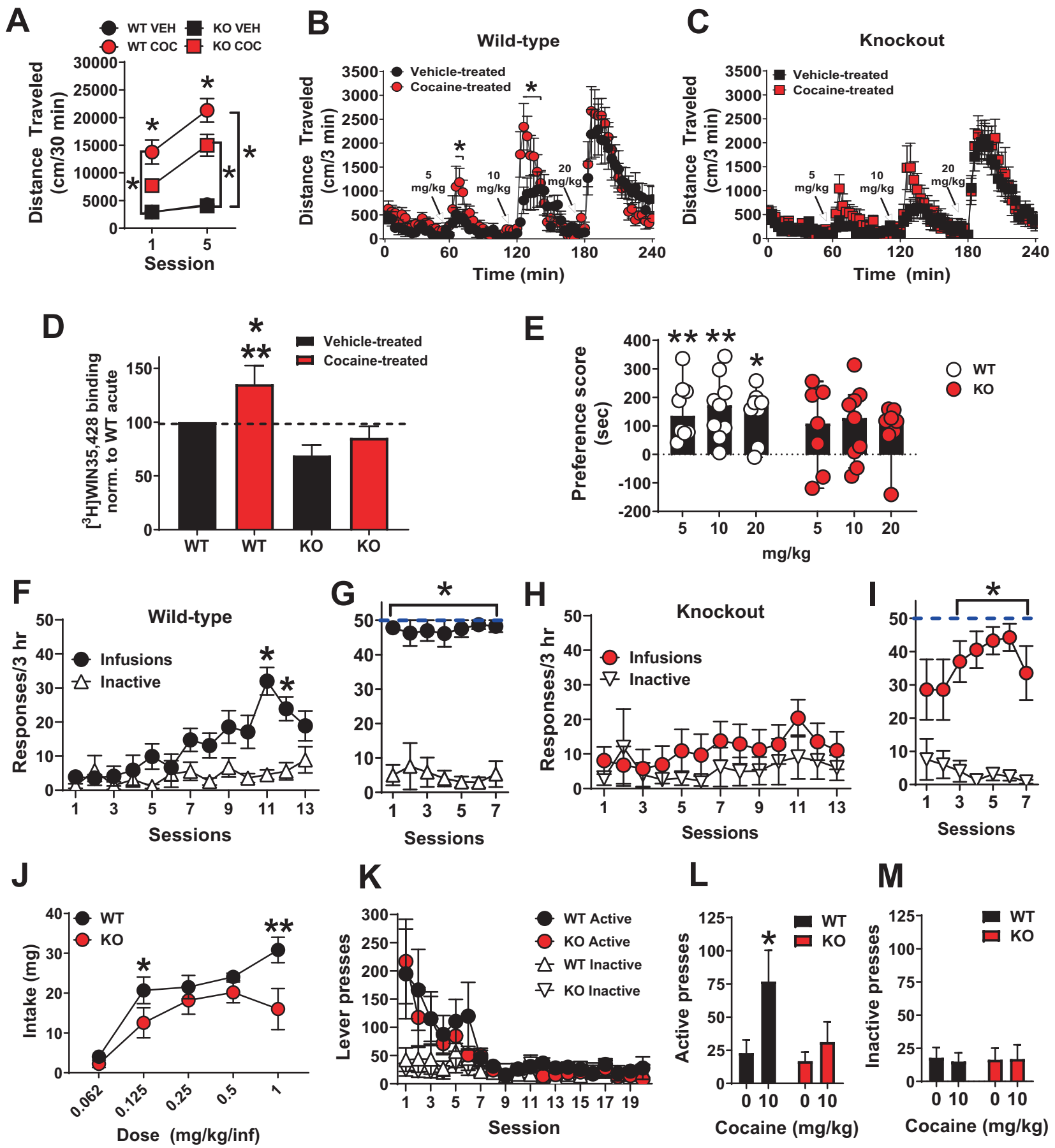

mice took longer ( 3 sessions) to learn to discriminate the cocaine-reinforced active lever over the inactive lever and also took longer (five sessions) to reach 50 infusions (Fig. 4l). Eventually, ZnT3 KO mice $(n=7)$ showed significantly greater cocaine-reinforced presses (two-way RM anova with Holm-Sidak multiple comparisons, lever $\times$ time interaction, $F(6,71)=3.9 ; p=$ 0.002 ) compared to inactive lever presses (session $3: t=4.74 ; p=$ 0.007 , session $4: t=7.03 ; p=0.002$, session $5: \mathrm{t}=8.86 ; p<0.001$, session $6: t=9.82 ; \mathrm{p}<0.001$, session $7: t=4.01 ; \mathrm{p}=0.04)$. After acquisition of cocaine SA, mice were tested at lower doses of cocaine. WT and KO mice did not differ in the number of cocaine infusions at these lower doses (Fig. S8). However, compared to
WT mice $(n=6)$, KO mice $(n=5)$ showed significantly lower cocaine intake (mixed effects RM analysis with Holm-Sidak multiple comparisons, genotype $\times$ dose interaction, $F(4,44)=$ $2.92)$ at $1 \mathrm{mg} / \mathrm{kg} / \mathrm{inf}$. ( $t=3.26 ; p=0.001)$ and at $0.125 \mathrm{mg} / \mathrm{kg} / \mathrm{inf}$. $(t=2.03 ; p=0.04)$ doses (Fig. 4J). Mice were then assessed for extinction of cocaine $S A$, but no genotype differences were observed (Fig. 4K). After mice had extinguished their lever responding for cocaine, they were tested for reinstatement (relapse) responding to a cocaine priming injection $(10 \mathrm{mg} / \mathrm{kg}$, IP). WT mice $(n=5)$ showed reinstatement of cocaine SA and significantly greater active lever presses (two-way RM anova with Holm-Sidak multiple comparisons, genotype $\times$ dose interaction, 
Fig. 4 Synaptic $\mathrm{Zn}^{2+}$ release potentiates cocaine locomotor sensitization, reward, seeking and is required for cocaine-induced increases in DAT. A ZnT3 knockout (KO) mice injected with $10 \mathrm{mg} / \mathrm{kg}$ cocaine (COC) showed significantly lower locomotor activity compared to cocaine-injected wild-type (WT) mice. Compared to vehicle, cocaine significantly increased locomotor activity in both WT and KO mice on Day 5 but only in WT mice on Day 1. B Cocaine-treated WT mice showed significantly greater expression of cocaine locomotor sensitization at 5 and $10 \mathrm{mg} / \mathrm{kg}$ cocaine compared to vehicle-treated WT mice. C Cocaine-treated ZnT3 KO mice do not differ in expression of cocaine locomotor sensitization compared to vehicle-treated KO mice. D Cocaine-treated WT mice had significantly greater DAT binding than cocainetreated ZnT3 KO mice and vehicle-treated KO mice and showed a trend toward significantly greater DAT binding than vehicle-treated WT mice. E WT mice showed significant preference for a chamber paired with cocaine at 5, 10, and $20 \mathrm{mg} / \mathrm{kg}$. ZnT3 $\mathrm{KO}$ mice did now show preference for a chamber paired with cocaine at any dose. F Wild-type mice exposed to a training dose of cocaine (1 mg/kg/inf.) showed significantly greater cocaine-reinforced presses compared to inactive lever presses. G Once trained, WT mice were exposed to a lower cocaine dose $(0.5 \mathrm{mg} / \mathrm{kg} / \mathrm{inf}$.), immediately reached the maximum number of presses allowed per session, and showed significantly greater cocainereinforced presses compared to inactive lever presses on all sessions. $\mathbf{H ~ Z n T 3 ~ k n o c k o u t ~ m i c e ~ e x p o s e d ~ t o ~ a ~ t r a i n i n g ~ d o s e ~ o f ~ c o c a i n e ~ ( 1 ~ m g / k g / ~}$ inf.) did not show any significant differences between cocaine-reinforced and inactive lever pressing. I ZnT3 knockout mice exposed to a lower cocaine dose $(0.5 \mathrm{mg} / \mathrm{kg} / \mathrm{inf}$.) showed significantly greater cocaine-reinforced presses compared to inactive lever presses during the last five sessions. J ZnT3 KO mice showed significantly lower cocaine intake at $1 \mathrm{mg} / \mathrm{kg} / \mathrm{inf}$. and at $0.125 \mathrm{mg} / \mathrm{kg} / \mathrm{inf}$. compared to WT mice. $\mathrm{K}$ WT and ZnT3 KO mice did not differ in extinction of cocaine self-administration. L After extinction of cocaine self-administration behavior, WT mice showed reinstatement of cocaine self-administration and significantly greater active lever presses after cocaine priming compared to ZnT3 KO mice. M WT and ZnT3 KO mice did not differ in inactive lever responding during cocaine-primed reinstatement. ${ }^{*} p \leq 0.05$. All data except E expressed as Mean \pm SEM. Panel E is expressed as Median $\pm 95 \% \mathrm{Cl}$.

$F(1,10)=5.09 ; p=0.04)$ after cocaine priming $(t=3.17 ; p=$ $0.005)$ compared to ZnT3 KO mice $(n=5)$, which did not reinstate (Fig. 4L, M). WT mice $(n=5)$ and ZnT3 KO mice $(n=5)$ did not differ in inactive lever responding (two-way RM anova with Holm-Sidak multiple comparisons, genotype $x$ dose interaction, $F(1,10)=0.17 ; p=0.68)$ during cocaine-primed reinstatement.

\section{Dietary $\mathrm{Zn}^{2+}$ deficiency decreases brain $\mathrm{Zn}^{2+}$ and attenuates cocaine locomotor sensitization, reward, and striatal DAT binding}

Synaptic $\mathrm{Zn}^{2+}$ levels and $\mathrm{ZnT3}$ expression are modulated by dietary $\mathrm{Zn}^{2+}$ intake $[30,31]$. Chronic drug abuse (including cocaine) in humans is associated with malnutrition and dysregulated peripheral $\mathrm{Zn}^{2+}$ levels [33-38]. However, whether dietary $\mathrm{Zn}^{2+}$ availability can modulate the behavioral effects of cocaine has not been previously reported.

To examine this, we fed mice, for approximately one month, diets that were custom-formulated by a commercial vendor to contain either 30 (considered an adequate level of $\mathrm{Zn}^{2+}$ intake) or 5 (a low amount of $\mathrm{Zn}^{2+}$ intake) ppm $\mathrm{Zn}^{2+}$. We first verified the $\mathrm{Zn}^{2+}$ content of each diet using TXRF. According to our measurements, the $30 \mathrm{ppm}$ diet contained $\sim 28 \mathrm{ppm} \mathrm{Zn}^{2+}$ and the $5 \mathrm{ppm}$ diet contained $\sim 8 \mathrm{ppm} \mathrm{Zn}^{2+}$ (Fig. 5A) (we will however refer to them here as 30 and $5 \mathrm{ppm} \mathrm{Zn}^{2+}$ diets to remain consistent with prior studies that have used similar formulations). Mice fed a $5 \mathrm{ppm} \mathrm{Zn}^{2+}$ diet $(n=32)$ did not differ in body weight from mice fed a $30 \mathrm{ppm} \mathrm{Zn}^{2+}$ diet $(n=32)$ (Fig. 5B). Mice fed a 5 ppm $\mathrm{Zn}^{2+}$ diet $(n=32)$ showed a significant decrease (two-way RM anova with Holm-Sidak multiple comparisons; genotype $\times$ time interaction, $F(15,930)=10.07 ; p<0.001)$ in food intake 3 days $(t=11.37 ; p<0.001)$ after diet initiation compared to mice fed a $30 \mathrm{ppm}$ diet $(n=32)$ though soon afterward normalized to the same levels of intake (Fig. 5C). The low $\mathrm{Zn}^{2+}$ diet was effective in decreasing brain $\mathrm{Zn}^{2+}$ content as mice fed a 5 ppm $\mathrm{Zn}^{2+}$ diet $(n$ $=7)$ showed significantly lower $\mathrm{Zn}^{2+}$ levels in frontal Ctx (unpaired $t$-test; $t=3.15 ; p=0.01$ ) compared to mice fed a 30 $\mathrm{pm} \mathrm{Zn}^{2+}$ diet $(n=5)$ as assessed via TXRF (Fig. 5D).

Next, we performed cocaine locomotor sensitization in $30 \mathrm{ppm}$ and $5 \mathrm{ppm}$ mice using the same procedures as in the above ZnT3 $\mathrm{KO}$ experiments. Mice fed $5 \mathrm{ppm}$ or $30 \mathrm{ppm} \mathrm{Zn}^{2+}$ diets did not differ in the development of cocaine locomotor sensitization (Fig. $5 \mathrm{E}) .30 \mathrm{ppm}$ diet-fed mice injected with cocaine $(n=14)$ showed significantly greater locomotor activity (two-way RM anova with Holm-Sidak multiple comparisons; genotype $\times$ session interaction, $F(3,52)=23.57 ; p<0.001)$ than $30 \mathrm{ppm}$ diet-fed mice injected with vehicle $(n=14)$ at Day $1(t=8.29 ; p<0.001)$ and Day $5(t=$ $14.27 ; p<0.001)$. Similarly, 5 ppm mice injected with cocaine $(n=$
14) showed significantly greater locomotor activity compared to 5 ppm mice injected with vehicle $(n=14)$ at Day $1(t=6.95 ; p<$ $0.001)$ and Day 5 ( $t=13.95 ; p<0.001)$. 30 ppm mice injected with cocaine also showed significantly greater locomotor activity at Day 5 than at Day $1(t=9.98 ; p<0.001)$ and 5 ppm mice injected with cocaine also showed significantly greater locomotor activity at Day 5 than at Day $1(t=10.06 ; p<0.001)$ (Fig. 5E). Seven days later, mice were examined for expression of cocaine locomotor sensitization. We found that cocaine-treated mice fed the $30 \mathrm{ppm}$ diet $(n=6)$ showed significantly greater expression of cocaine locomotor sensitization (two-way RM anova with Holm-Sidak multiple comparisons; genotype $\times$ time interaction, $F(79,790)=$ $3.98 ; p<0.001)$ at $5(66 \mathrm{~min} ; t=5.69 ; p<0.001,69 \mathrm{~min} ; t=4.68 ; p$ $<0.001$, $72 \mathrm{~min} ; t=3.76 ; p=0.01,75 \mathrm{~min} ; t=3.78 ; p=0.01$, $78 \min ; t=4.29 ; p=0.001,81 \min ; \mathrm{t}=3.79 ; p=0.01,84 \min ; t=$ 4.23; $p=0.002), 10 \mathrm{mg} / \mathrm{kg}(123 \mathrm{~min} ; \mathrm{t}=5.37 ; p<0.001,126 \mathrm{~min} ; t$ $=7.42 ; p<0.001,129 \mathrm{~min} ; t=6.99 ; p<0.001,132 \mathrm{~min} ; t=6.58 ; p$ $=0.01,135 \mathrm{~min} ; t=5.08 ; p=0.03,138 \mathrm{~min} ; \mathrm{t}=5.36 ; p=0.03$, $141 \mathrm{~min} ; t=4.39 ; p=0.03,144 \mathrm{~min} ; \mathrm{t}=4.14 ; \mathrm{p}=0.03,147 \mathrm{~min} ; t$ $=3.78 ; p=0.03$ ) and $20 \mathrm{mg} / \mathrm{kg}$ cocaine (183 $\mathrm{min} ; t=3.43 ; p=$ $0.04)$ compared to vehicle-treated mice fed the same $30 \mathrm{ppm}$ diet $(n=13)$ (Fig. 5F). In contrast, cocaine-treated mice fed the $5 \mathrm{ppm}$ diet $(n=6)$ did not show a significant difference in expression of locomotor sensitization compared to vehicle-treated mice fed the 5 ppm diet $(n=6)$ (two-way RM anova with Holm-Sidak multiple comparisons; genotype $\times$ time interaction, $F(79,790)=0.9342 ; p$ $=0.64$ ) (Fig. 5G).

Next, we tested whether mice fed 30 ppm and 5 ppm $\mathrm{Zn}^{2+}$ diets differed in cocaine preference using the same CPP procedure as in $\mathrm{ZnT3}$ KO mice. Mice fed the $30 \mathrm{ppm} \mathrm{Zn}^{2+}$ diet showed significant preference (one sample Wilcoxon test with theoretical median set to 0$)$ for the chamber paired with cocaine at $5 \mathrm{mg} / \mathrm{kg}(n=8)(p=$ 0.007; 95\% Cl: 45.8-205.5), $10 \mathrm{mg} / \mathrm{kg}(n=8)(p=0.007 ; 95 \% \mathrm{Cl}$ : 42.6-245.4), and $20 \mathrm{mg} / \mathrm{kg}(n=7)(p=0.003 ; 95 \% \mathrm{Cl}:-6.0$ to 149.6). Mice fed a $5 \mathrm{ppm} \mathrm{Zn}^{2+}$ diet showed significant preference (one sample Wilcoxon test with theoretical median set to 0 ) for the chamber paired with cocaine at $10 \mathrm{mg} / \mathrm{kg}(n=8)(p=0.039 ; 95 \%$ Cl: -79.8 to 298.0$)$, and $20 \mathrm{mg} / \mathrm{kg}(n=8)(p=0.007 ; 95 \% \mathrm{Cl}$ : $26.2-185.9)$ but not at $5 \mathrm{mg} / \mathrm{kg}(n=8)(p=0.10 ; 95 \% \mathrm{Cl}:-30.1$ to 125.7) (Fig. 5H).

Finally, we examined whether dietary $\mathrm{Zn}^{2+}$ availability had any effects on DAT binding in the striatum. Mice fed $30 \mathrm{ppm}$ and 5 ppm $\mathrm{Zn}^{2+}$ diets and exposed to escalating cocaine injections (5, 10 , and $20 \mathrm{mg} / \mathrm{kg}$, IP, one injection/h) were euthanized $24 \mathrm{~h}$ after the last injection and their brains were assessed for striatal $\left[{ }^{3} \mathrm{H}\right]$ WIN-35,428 binding. We found that mice exposed to cocaine and a $5 \mathrm{ppm} \mathrm{Zn}^{2+}$ diet $(n=6)$ showed significantly lower striatal DAT binding (Fig. 5I) (unpaired t-test; $t=9.63 ; p<0.001$ ) (3 repetitions 
A

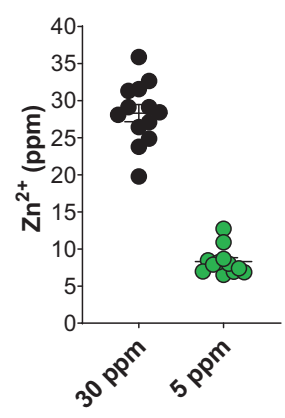

E

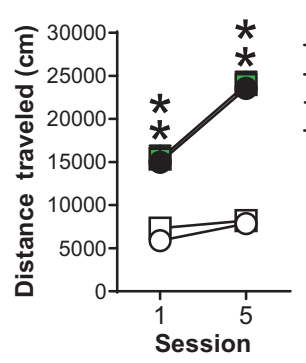

B

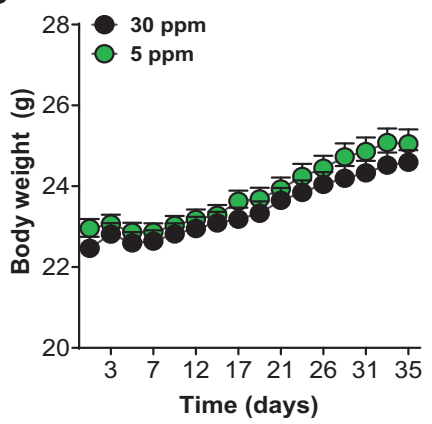

C

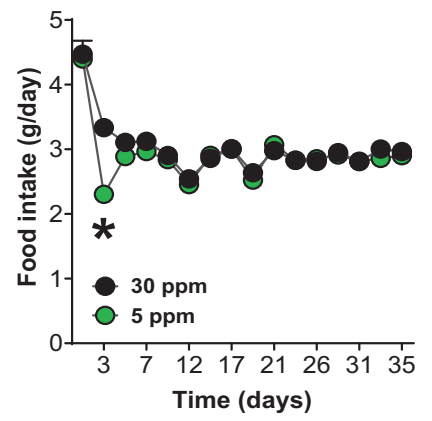

D

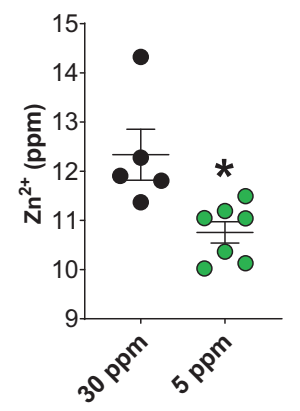

F

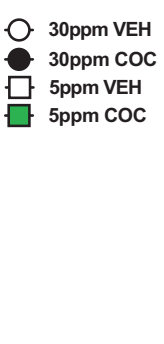

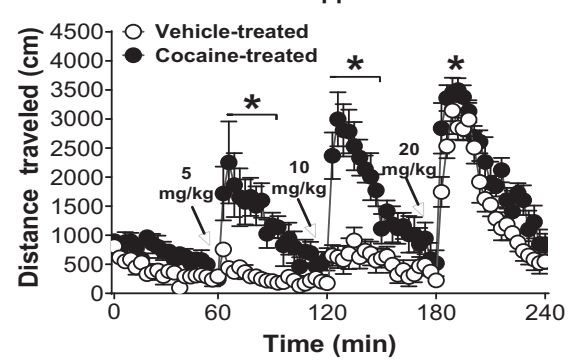

G

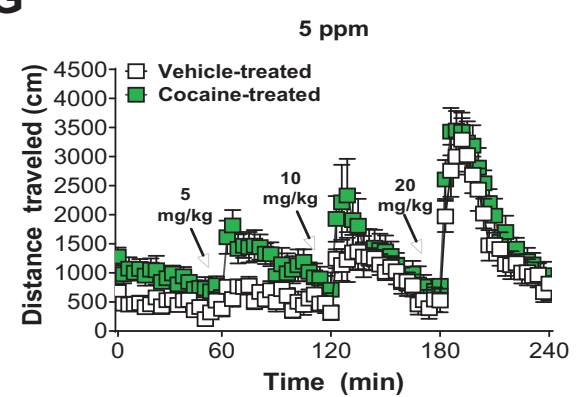

H

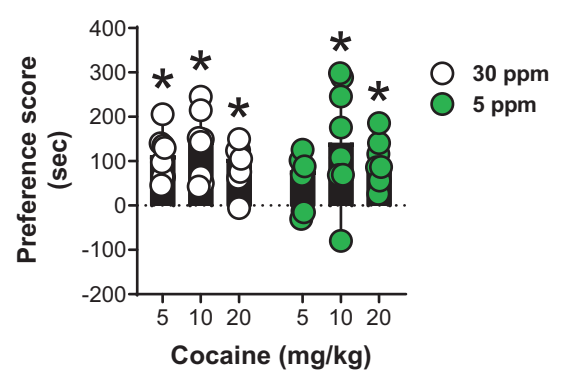

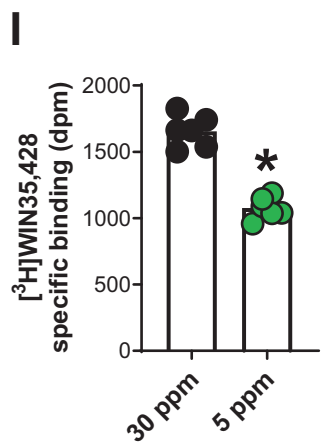

J

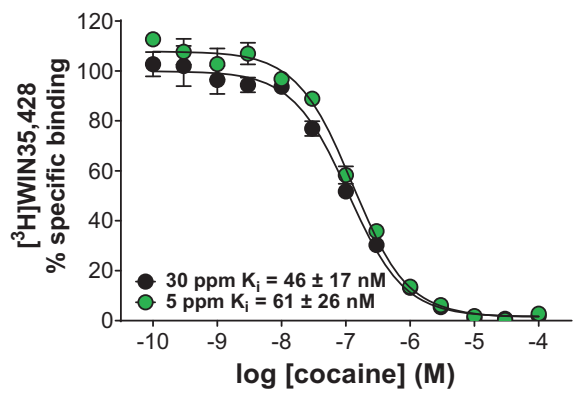

Fig. 5 Dietary $\mathrm{Zn}^{2+}$ deficiency decreases brain $\mathrm{Zn}^{2+}$ and attenuates cocaine locomotor sensitization, reward, and striatal DAT binding. A Total reflection X-ray spectroscopy (TXRF)-based verification of $\mathrm{Zn}^{2+}$ content in custom-made diets. B Mice fed a 5 ppm $\mathrm{Zn}{ }^{2+}$ diet did not

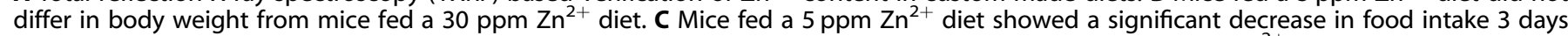
after diet initiation compared to mice fed a $30 \mathrm{ppm}$ diet but did not differ at other times. D Mice fed a $5 \mathrm{ppm} Z \mathrm{n}^{2+}$ diet showed significantly lower total $\mathrm{Zn}^{2+}$ in frontal/cingulate cortex compared to mice fed a $30 \mathrm{pm} \mathrm{Zn^{2+ }}$ diet. E Mice fed 5 ppm or 30 ppm Zn ${ }^{2+}$ diets did not differ in development of cocaine (COC) locomotor sensitization (VEH- vehicle). F Cocaine-treated $30 \mathrm{ppm}$ diet mice $(n=6)$ showed significantly greater expression of cocaine locomotor sensitization at $5,10 \mathrm{mg} / \mathrm{kg}$ and $20 \mathrm{mg} / \mathrm{kg}$ cocaine compared to vehicle-treated $30 \mathrm{ppm}$ mice $(n=13)$. G Cocaine-treated $5 \mathrm{ppm}$ mice did not show any significant difference in expression of locomotor sensitization compared to vehicle-treated 5

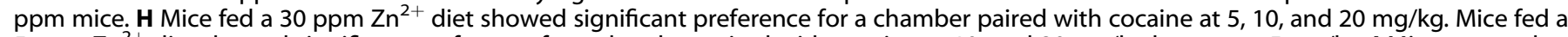
$5 \mathrm{ppm} \mathrm{Zn}^{2+}$ diet showed significant preference for a chamber paired with cocaine at 10 , and $20 \mathrm{mg} / \mathrm{kg}$ but not at $5 \mathrm{mg} / \mathrm{kg}$. I Mice exposed to cocaine and a 5 ppm $\mathrm{Zn}^{2+}$ diet showed significantly lower DAT binding in striatum and $\mathbf{J}$ a mild decrease in cocaine affinity compared to mice exposed to cocaine and a $30 \mathrm{ppm}$ diet. dpm - disintegrations per minute. ${ }^{*} p \leq 0.05$. All data except panel $\mathrm{H}$ expressed as Mean $\pm \mathrm{SEM}$. Panel $\mathrm{H}$ is expressed as Median $\pm 95 \% \mathrm{Cl}$.

per group, in triplicate) and a decrease in cocaine affinity compared to mice exposed to cocaine and a $30 \mathrm{ppm} \mathrm{Zn}^{2+}$ diet $(n=6)\left(5 \mathrm{ppm} K_{\mathrm{i}}=61 \pm 26 \mathrm{nM} ; 30 \mathrm{ppm} \mathrm{Ki}=46 \pm 17 \mathrm{nM}\right)(3$ repetitions per curve, in triplicate) (Fig. $5 \mathrm{~J}$ ).

\section{DISCUSSION}

Here we show that human subjects who died of cocaine overdose had significantly lower $\mathrm{Zn}^{2+}$ content in the striatum (caudate) compared to matched controls. We also show that striatal $\mathrm{Zn}^{2+}$ levels in these subjects negatively correlated with plasma levels of benzoylecgonine, indicating that low striatal $\mathrm{Zn}^{2+}$ levels were associated with greater cocaine intake.
To further explore the relationship between cocaine exposure and striatal $\mathrm{Zn}^{2+}$, we performed studies using mice lacking $\mathrm{ZnT3}$, a neuronal $\mathrm{Zn}^{2+}$ transporter necessary for synaptic $\mathrm{Zn}^{2+}$ release. We found that $\mathrm{RC}$ injections increased striatal $\mathrm{Zn}^{2+}$ content (in $\mathrm{CPu}$ and NAc) in normal mice but not in mice lacking $\mathrm{ZnT3}$, indicating that cocaine exposure increases synaptic $\mathrm{Zn}^{2+}$ levels in the striatum via the actions of $Z n T 3$. We also found that RC injections increased $\mathrm{Zn}^{2+}$ uptake in regions with high synaptic $\mathrm{Zn}^{2+}$ and $\mathrm{ZnT3}$ content, including the NAc indicating that cocaine exposure increases synaptic $\mathrm{Zn}^{2+}$ turnover/metabolism in these regions.

We hypothesized that cocaine-induced increases in synaptic $\mathrm{Zn}^{2+}$ release would be relevant to cocaine's in vivo actions at the DAT, given the known in vitro interactions between $\mathrm{Zn}^{2+}$, DAT, 

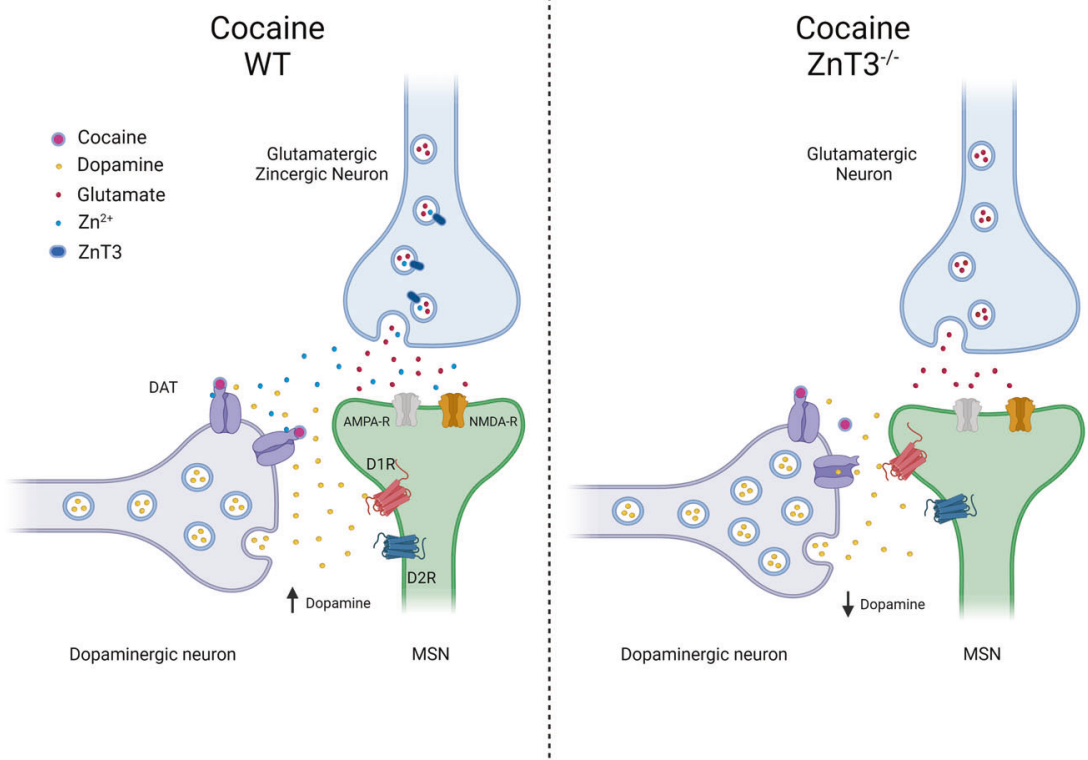

Fig. 6 Schematic representation of the putative mechanism by which presynaptic $\mathrm{Zn}^{2+}$ modulates the effects of cocaine on dopamine and glutamate neurotransmission in the striatum in wild-type (WT) and ZnT3 knockout mice. The image on the left shows the effect of synaptic $\mathrm{Zn}^{2+}$ on increasing cocaine's efficacy by binding to the DAT on dopaminergic neurons. It also acknowledges the putative effects of $\mathrm{Zn}^{2+}$ on glutamate neurotransmission in the context of cocaine via its interaction with AMPA and NMDA receptors. The image on the right illustrates the effect of ZnT3 deletion, and consequently the loss of presynaptic $\mathrm{Zn}^{2+}$ release, in attenuating the effects of cocaine on striatal dopamine and glutamate neurotransmission.

and cocaine. Using in vitro assays, we first confirmed that a physiologically-relevant concentration of $\mathrm{Zn}^{2+}$ increased the ability of cocaine to bind to DAT. Then, to extend the relevance of this finding to an in vivo context, we used in vivo FSCV and found that deletion of $\mathrm{ZnT3}$, and hence, loss of synaptic $\mathrm{Zn}^{2+}$ release, attenuated cocaine's effects on striatal DA neurotransmission. Consistent with this observation, mice lacking ZnT3 were insensitive to cocaine-induced increases in striatal DAT binding and showed attenuated behavioral responses to cocaine in several procedures such as locomotor sensitization, CPP, and IV SA, indicating that synaptic $\mathrm{Zn}^{2+}$ promotes cocaine sensitization, reward, and cocaine-seeking behavior.

$\mathrm{Zn}^{2+}$ is obtained almost exclusively from the diet. Taking our above findings into account, we reasoned that low environmental availability of $\mathrm{Zn}^{2+}$ and specifically, reduced dietary $\mathrm{Zn}^{2+}$ intake, would attenuate behavioral responses to cocaine. As predicted, we found that mice exposed to a diet with low $\mathrm{Zn}^{2+}$ content showed lower brain $\mathrm{Zn}^{2+}$ levels, decreased cocaine-induced increases in striatal DAT binding, and attenuated behavioral responses to cocaine compared to mice fed a diet with adequate $\mathrm{Zn}^{2+}$ content. This indicates that low dietary $\mathrm{Zn}^{2+}$ intake decreases brain $\mathrm{Zn}^{2+}$ levels, and attenuates cocaine locomotor sensitization, cocaine preference, and cocaine-induced increases in striatal DAT.

Taken together, our above findings suggest that synaptic $\mathrm{Zn}^{2+}$ release in the striatum plays a critical role in cocaine's effects on striatal DA neurotransmission and consequently in the neurobiological and behavioral adaptations associated with cocaine exposure. A summary depicting this proposed mechanism is shown in Fig. 6.

The results from our experiments in mice suggest that the $\mathrm{Zn}^{2+}$ deficits we identified in humans who died from cocaine overdose may arise from a combination of inadequate nutrition (i.e. low dietary $\mathrm{Zn}^{2+}$ intake) and increased $\mathrm{Zn}^{2+}$ turnover/metabolism brought upon by chronic cocaine use, although we cannot rule out individual or combined contributions of diet, cocaine use, or use of other drugs/substances in these effects. The negative correlation between striatal $\mathrm{Zn}^{2+}$ content and plasma benzoylecgonine levels in postmortem human samples, taken together with the rest of our data, may reflect the notion that individuals with inherently low striatal $\mathrm{Zn}^{2+}$ levels would be less sensitive to the effects of cocaine and therefore would need to compensate by consuming more of the drug. This would implicate $\mathrm{Zn}^{2+}$ as an environmental factor that could influence vulnerability to the effects of cocaine and potentially to the development of cocaine use disorders or addiction.

Our results have important implications for both general DAdependent behaviors and especially for the prevention and treatment of cocaine addiction. Specifically, our findings suggest that dietary $\mathrm{Zn}^{2+}$ intake, and potentially, impaired $\mathrm{Zn}^{2+}$ absorption or excretion mechanisms, are implicated in cocaine reward, seeking, and relapse. Consequently, we suggest that the $\mathrm{Zn}^{2+}$ status of patients with cocaine addiction should be taken into consideration, especially since $\mathrm{Zn}^{2+}$ deficiency varies in prevalence across social demographics and is found in higher proportion in developing countries [32].

Our findings also expand the current understanding of cocaine's neurobiological effects. DA and glutamate systems converge at the level of the striatum to modulate behaviors that influence cocaine seeking and abuse $[46,63]$. Synaptic $\mathrm{Zn}^{2+}$, mediated by $\mathrm{ZnT3}$, is packaged along with glutamate in the same synaptic vesicles and is released by glutamatergic terminals in the striatum upon neuronal activation. As such, the cocaine-induced synaptic $\mathrm{Zn}^{2+}$ increases we report here would be expected to accompany the well-described increase in synaptic glutamate neurotransmission in the striatum following RC exposure [45, 46, 64, 65]. Indeed, cocaine-induced increases in synaptic glutamate are thought to result, in part, from reductions in extrasynaptic glutamate arising from decreased cystine-glutamate exchange in response to $\operatorname{RC}$ use $[63,66]$. Specifically, cocaine-induced reductions in extrasynaptic glutamate weaken signaling at presynaptic metabotropic glutamate receptors, thereby increasing synaptic glutamate levels [64] and resulting in 
excitatory synaptic strengthening. This mechanism may underlie the increases in cocaine-induced synaptic $\mathrm{Zn}^{2+}$ that we observe.

$\mathrm{Zn}^{2+}$ binds to NMDA and AMPA receptors $[67,68]$ and it is likely that, in addition to affecting DA neurotransmission via binding to DAT, cocaine-induced increases in synaptic $\mathrm{Zn}^{2+}$ release may also exert direct allosteric interactions at ionotropic glutamate receptors to influence cocaine-dependent glutamate neurotransmission, synaptic plasticity, and behaviors such as cocaine locomotor sensitization and cocaine priming-induced reinstatement of cocaine seeking $[45,46,65,69]$. However, the precise mechanism for how cocaine-induced $\mathrm{Zn}^{2+}$ release would lead to such effects is complicated by the fact that $\mathrm{Zn}^{2+}$ can exert bidirectional effects at AMPA receptors [70], it can inhibit both synaptic and extrasynaptic NMDA receptors [68], and finally, that cocaine induces projection- and cell type-specific adaptations in the NAc [71], that not all NAc glutamatergic synapses release $\mathrm{Zn}^{2+}$ and that the specific zincergic synapses, and the postsynaptic cells they target in regions such as the NAc have not yet been defined. For all these reasons, the specific effects of cocaine-induced $\mathrm{Zn}^{2+}$ release on glutamatergic signaling are unclear and require further investigation.

Another possibility may be that $\mathrm{Zn}^{2+}$ interacts with cystineglutamate exchange mechanisms directly to produce changes in cocaine behaviors. Indeed, we found here that $\mathrm{ZnT3}$ KO mice failed to reinstate cocaine-primed SA of cocaine, suggesting that synaptic $\mathrm{Zn}^{2+}$ release is necessary for cocaine-primed seeking. $\mathrm{N}$-acetylcysteine (NAC) is a derivative of the amino acid cysteine and has been proposed as a treatment for substance use disorders [72]. NAC prevents cocaine-primed reinstatement of drug seeking after cocaine SA by stimulating cystine-glutamate exchange [63]. Importantly, NAC also has metal-chelating capabilities $\left(\mathrm{Zn}^{2+}\right.$ binds with high affinity to cysteines [73]) and systemic administration of $\mathrm{NAC}$ in mice has been shown to decrease peripheral $\mathrm{Zn}^{2+}$ levels [74]. Accordingly, it may be possible that in addition to the effects of NAC in decreasing cocaine-primed seeking via activation of cystine-glutamate exchange, its effects may also be driven, in part, via direct interaction with synaptic $\mathrm{Zn}^{2+}$. In this case, NAC would effectively act as a $\mathrm{Zn}^{2+}$ chelating agent, decreasing synaptic $\mathrm{Zn}^{2+}$ levels, which would attenuate cocaine's effects at the DAT and decrease cocaine-seeking. However, this could also occur concomitantly to NAC's activation of cystine-glutamate exchange, which would increase extrasynaptic glutamate to restore presynaptic metabotropic glutamate receptor tone and thereby reduce synaptic glutamate and potentially, co-released $\mathrm{Zn}^{2+}$.

In addition to cocaine, other psychostimulants interact with the DAT to produce their effects of behavior. We propose that the cocaine-dependent changes in $\mathrm{Zn}^{2+}$ that we describe here are not specific to cocaine but may also be elicited by other psychostimulants that modulate DAT function and increase corticostriatal glutamate neurotransmission [45, 46, 75], and potentially other drugs of abuse, including alcohol [76] which is strongly associated with $\mathrm{Zn}^{2+}$ deficiency [76].

Finally, in addition to its critical role in addiction, the DAT is the primary molecular target for stimulant medications used in the treatment of attention-deficit hyperactivity disorder (ADHD). Studies indicate that medication response is reduced in $\mathrm{Zn}^{2+}$ deficient ADHD patients [77]. Our findings here offer a mechanistic explanation for these clinical observations and suggest that $\mathrm{Zn}^{2+}$ supplementation may improve the efficacy of stimulant-based ADHD medications.

In conclusion, our findings expand current knowledge regarding the direct pharmacological mechanism of action of cocaine and the neurobiological mechanisms involved in cocaine's behavioral effects by identifying a critical role for the trace element $\mathrm{Zn}^{2+}$ as an environmentally derived modulator of cocaine affinity, potency, plasticity, reward, and seeking.
DATA AVAILABILITY

All data are available within the article or its supplementary material.

\section{REFERENCES}

1. Frederickson CJ, Suh SW, Silva D, Thompson RB. Importance of zinc in the central nervous system: the zinc-containing neuron. J Nutr. 2000;130:1471s-1483s.

2. Gower-Winter SD, Levenson CW. Zinc in the central nervous system: from molecules to behavior. Biofactors. 2012;38:186-93.

3. Pfeiffer CC, Braverman ER. Zinc, the brain and behavior. Biol Psychiatry. 1982;17:513-32.

4. Sensi SL, Paoletti P, Koh JY, Aizenman E, Bush Al, Hershfinkel M. The neurophysiology and pathology of brain zinc. J Neurosci. 2011;31:16076-85.

5. Cuajungco MP, Lees GJ. Zinc metabolism in the brain: relevance to human neurodegenerative disorders. Neurobiol Dis. 1997;4:137-69.

6. McAllister BB, Dyck RH. Zinc transporter $3(\mathrm{ZnT3})$ and vesicular zinc in central nervous system function. Neurosci Biobehav Rev. 2017;80:329-50.

7. Pe'rez-Clausell J, Danscher G. Intravesicular localization of zinc in rat telencephalic boutons. A histochemical study. Brain Res. 1985;337:91-98.

8. Brown CE, Dyck RH. Distribution of zincergic neurons in the mouse forebrain. J Comp Neurol. 2004:479:156-67.

9. Palmiter RD, Cole TB, Quaife CJ, Findley SD. ZnT-3, a putative transporter of zinc into synaptic vesicles. Proc Natl Acad Sci USA. 1996;93:14934-9.

10. Cole TB, Wenzel HJ, Kafer KE, Schwartzkroin PA, Palmiter RD. Elimination of zinc from synaptic vesicles in the intact mouse brain by disruption of the ZnT3 gene. Proc Natl Acad Sci USA. 1999;96:1716-21.

11. Thackray SE, McAllister BB, Dyck RH. Behavioral characterization of female zinc transporter 3 (ZnT3) knockout mice. Behav Brain Res. 2017;321:36-49.

12. Cole TB, Martyanova A, Palmiter RD. Removing zinc from synaptic vesicles does not impair spatial learning, memory, or sensorimotor functions in the mouse. Brain Res. 2001;891:253-65.

13. Martel G, Hevi C, Friebely O, Baybutt T, Shumyatsky GP. Zinc transporter 3 is involved in learned fear and extinction, but not in innate fear. Learn Mem. 2010;17:582-90.

14. Kumar M, Xiong S, Tzounopoulos $T$, Anderson CT. Fine control of sound frequency tuning and frequency discrimination acuity by synaptic zinc signaling in mouse auditory cortex. J Neurosci. 2019;39:854-65.

15. Patrick WuHP, Dyck RH. Signaling by synaptic zinc is required for whiskermediated, fine texture discrimination. Neuroscience. 2018;369:242-7.

16. Frederickson CJ, Giblin LJ, Krężel A, McAdoo DJ, Muelle RN, Zeng Y, et al. Concentrations of extracellular free zinc (pZn)e in the central nervous system during simple anesthetization, ischemia and reperfusion. Exp Neurol. 2006;198:285-93.

17. Frederickson CJ, Giblin $L$, Rengarajan B, Masalha R, Frederickson CJ, Zeng Y, et al. Synaptic release of zinc from brain slices: factors governing release, imaging, and accurate calculation of concentration. J Neurosci Methods. 2006;154:19-29.

18. Wu Q, Coffey LL, Reith ME. Cations affect [3H]mazindol and [3H]WIN 35,428 binding to the human dopamine transporter in a similar fashion. J Neurochem. 1997:69:1106-18.

19. Scholze P, Norregaard L, Singer EA, Freissmuth M, Gether U, Sitte HH. The role of zinc ions in reverse transport mediated by monoamine transporters. J Biol Chem. 2002;277:21505-13.

20. Liang YJ, Zhen J, Chen N, Reith ME. Interaction of catechol and non-catechol substrates with externally or internally facing dopamine transporters. J Neurochem. 2009;109:981-94.

21. Hong WC, Amara SG. Membrane cholesterol modulates the outward facing conformation of the dopamine transporter and alters cocaine binding. J Biol Chem. 2010;285:32616-26.

22. Norregaard L, Frederiksen D, Nielsen EO, Gether U. Delineation of an endogenous zinc-binding site in the human dopamine transporter. Embo J. 1998;17:4266-73.

23. Kuhar MJ, Ritz MC, Boja JW. The dopamine hypothesis of the reinforcing properties of cocaine. Trends Neurosci. 1991;14:299-302.

24. Volkow ND, Wang GJ, Fischman MW, Foltin RW, Fowler JS, Abumrad NN, et al. Relationship between subjective effects of cocaine and dopamine transporter occupancy. Nature. 1997;386:827-30.

25. Wise RA, Bozarth MA. A psychomotor stimulant theory of addiction. Psychol Rev. 1987;94:469-92.

26. Mengual E, Casanovas-Aguilar C, Pérez-Clausell J, Giménez-Amaya JM. Heterogeneous and compartmental distribution of zinc in the striatum and globus pallidus of the rat. Neuroscience. 1995;66:523-37.

27. Frederickson CJ, Rampy BA, Reamy-Rampy S, Howell GA. Distribution of histochemically reactive zinc in the forebrain of the rat. J Chem Neuroanat. 1992;5:521-30. 
28. Ciliax BJ, Drash GW, Staley JK, Haber S, Mobley CJ, Miller GW, et al. Immunocytochemical localization of the dopamine transporter in human brain. J Comp Neurol. 1999;409:38-56.

29. Sikora J, Kieffer BL, Paoletti P, Ouagazzal AM. Synaptic zinc contributes to motor and cognitive deficits in 6-hydroxydopamine mouse models of Parkinson's disease. Neurobiol Dis. 2020;134:104681.

30. Grabrucker S, Jannetti L, Eckert M, Gaub S, Chhabra R, Pfaender S, et al. Zinc deficiency dysregulates the synaptic ProSAP/Shank scaffold and might contribute to autism spectrum disorders. Brain. 2013;137:137-52.

31. Takeda A, Hirate M, Tamano H, Nisibaba D, Oku N. Susceptibility to kainateinduced seizures under dietary zinc deficiency. J Neurochem. 2003;85:1575-80.

32. Prasad AS. Discovery of human zinc deficiency: its impact on human health and disease. Adv Nutr. 2013;4:176-90.

33. Santolaria-Fernandez FJ, Gomez-Sirvent JL, Gonzalez-Reimers CE, Batista-Lopez $\mathrm{JN}$, Jorge-Hernandez JA, Rodriguez-Moreno $\mathrm{F}$, et al. Nutritional assessment of drug addicts. Drug Alcohol Depend. 1995;38:11-18.

34. Comai S, Bertazzo A, Vachon J, Daigle M, Toupin J, Cote G, et al. Trace elements among a sample of prisoners with mental and personality disorders and aggression: correlation with impulsivity and ADHD indices. J Trace Elem Med Biol. 2019;51:123-9.

35. Sadlik J, Pach J, Winnik L, Piekoszewski W. [Concentration of zinc, copper and magnesium in the serum of drug addicts]. Przegl Lek. 2000;57:563-4.

36. Cheng FL, Wang $\mathrm{H}, \mathrm{Wu} J$, Ning MX, Hu LF, Su YL. [Determination and correlation analysis of trace elements in hair of dependence drug addicts]. Guang Pu Xue Yu Guang Pu Fen Xi. 2005;25:116-8.

37. Ruiz Martinez M, Gil Extremera B, Maldonado Martin A, Cantero-Hinojosa J, Moreno-Abadia V. Trace elements in drug addicts. Klin Wochenschr. 1990;68:507-11.

38. Hossain KJ, Kamal MM, Ahsan M, Islam SN. Serum antioxidant micromineral (Cu, $\mathrm{Zn}, \mathrm{Fe}$ ) status of drug dependent subjects: influence of illicit drugs and lifestyle. Subst Abus Treat Prev Policy. 2007;2:12. p

39. Bannon MJ, Johnson MM, Michelhaugh SK, Hartley ZJ, Halter SD, David JA, et al. A molecular profile of cocaine abuse includes the differential expression of genes that regulate transcription, chromatin, and dopamine cell phenotype. Neuropsychopharmacology. 2014;39:2191-9.

40. Zhou Y, Michelhaugh SK, Schmidt CJ, Liu JS, Bannon MJ, Lin Z. Ventral midbrain correlation between genetic variation and expression of the dopamine transporter gene in cocaine-abusing versus non-abusing subjects. Addict Biol. 2014;19:122-31.

41. Stan AD, Ghose S, Gao XM, Roberts RC, Lewis-Amezcua K, Hatanpaa KJ, et al. Human postmortem tissue: what quality markers matter? Brain Res. 2006;1123:1-11.

42. Michaelides M, Pascau J, Gispert JD, Delis F, Grandy DK, Wang GJ, et al. Dopamine D4 receptors modulate brain metabolic activity in the prefrontal cortex and cerebellum at rest and in response to methylphenidate. Eur $\mathrm{J}$ Neurosci. 2010;32:668-76.

43. Keighron JD, Quarterman JC, Cao J, DeMarco EM, Coggiano MA, Gleaves A, et al. Effects of (R)-modafinil and modafinil analogues on dopamine dynamics assessed by voltammetry and microdialysis in the mouse nucleus accumbens shell. ACS Chem Neurosci. 2019;10:2012-21.

44. Ho J, Tumkaya T, Aryal S, Choi H, Claridge-Chang A. Moving beyond P values: data analysis with estimation graphics. Nat Methods. 2019;16:565-6.

45. Scofield MD, Heinsbroek JA, Gipson CD, Kupchik YM, Spencer S, Smith AC, et al. The nucleus accumbens: mechanisms of addiction across drug classes reflect the importance of glutamate homeostasis. Pharm Rev. 2016;68:816-71.

46. Schmidt HD, Pierce RC. Cocaine-induced neuroadaptations in glutamate transmission: Potential therapeutic targets for craving and addiction. Ann N Y Acad Sci. 2010;1187:35-75.

47. Proebstl L, Kamp F, Manz K, Krause D, Adorjan K, Pogarell O, et al. Effects of stimulant drug use on the dopaminergic system: a systematic review and metaanalysis of in vivo neuroimaging studies. Eur Psychiatry. 2019;59:15-24.

48. Little KY, Zhang L, Desmond T, Frey KA, Dalack GW, Cassin BJ. Striatal dopaminergic abnormalities in human cocaine users. Am J Psychiatry. 1999;156:238-45.

49. Jufer RA, Wstadik A, Walsh SL, Levine BS, Cone EJ. Elimination of cocaine and metabolites in plasma, saliva, and urine following repeated oral administration to human volunteers. J Anal Toxicol. 2000;24:467-77.

50. Qin Z, Caruso JA, Lai B, Matusch A, Becker JS. Trace metal imaging with high spatial resolution: applications in biomedicine. Metallomics. 2011;3:28-37.

51. Linkous DH, Flinn JM, Koh JY, Lanzirotti A, Bertsch PM, Jones BF, et al. Evidence that the ZNT3 protein controls the total amount of elemental zinc in synaptic vesicles. J Histochem Cytochem. 2008;56:3-6. pp

52. Danscher G, Stoltenberg M. Zinc-specific autometallographic in vivo selenium methods: tracing of zinc-enriched (ZEN) terminals, ZEN pathways, and pools of zinc ions in a multitude of other ZEN cells. J Histochem Cytochem. 2005;53:141-53.
53. Sorensen JC, Slomianka L, Christensen J, Zimmer J. Zinc-containing telencephalic connections to the rat striatum: a combined Fluoro-Gold tracing and histochemical study. Exp Brain Res. 1995;105:370-82.

54. Takeda A, Sawashita J, Okada S. Biological half-lives of zinc and manganese in rat brain. Brain Res. 1995;695:53-58.

55. Pullen RGL, Franklin PA, Hall GH. 65Zn uptake from blood into brain in the rat. J Neurochemistry. 1991;56:485-9.

56. Takeda A, Hirate M, Oku N. Elimination of zinc- 65 from the brain under kainateinduced seizures. Biometals. 2004;17:141-4.

57. Takeda A, Kodama Y, Ohnuma M, Okada S. Zinc transport from the striatum and substantia nigra. Brain Res Bull. 1998:47:103-6.

58. Takeda A, Minami A, Takefuta S, Tochigi M, Oku N. Zinc homeostasis in the brain of adult rats fed zinc-deficient diet. J Neurosci Res. 2001;63:447-52.

59. Wang F, Dufner-Beattie J, Kim BE, Petris MJ, Andrews G, Eide DJ. Zinc-stimulated endocytosis controls activity of the mouse ZIP1 and ZIP3 zinc uptake transporters. J Biol Chem. 2004;279:24631-9.

60. Bjorklund NL, Volz TJ, Schenk JO. Differential effects of $\mathrm{Zn} 2+$ on the kinetics and cocaine inhibition of dopamine transport by the human and rat dopamine transporters. Eur J Pharmacol. 2007;565:17-25.

61. Pifl $C$, Wolf $A$, Rebernik $P$, Reither $H$, Berger ML. Zinc regulates the dopamine transporter in a membrane potential and chloride dependent manner. Neuropharmacology. 2009;56:531-40.

62. Malison RT, Best SE, van Dyck $C H$, McCance EF, Wallace EA, Laruelle $M$, et al. Elevated striatal dopamine transporters during acute cocaine abstinence as measured by [123I] beta-CIT SPECT. Am J Psychiatry. 1998;155:832-4.

63. Baker DA, McFarland K, Lake RW, Shen H, Tang XC, Toda S, et al. Neuroadaptations in cystine-glutamate exchange underlie cocaine relapse. Nat Neurosci. 2003;6:743-9.

64. Moran MM, McFarland K, Melendez RI, Kalivas PW, Seamans JK. Cystine/glutamate exchange regulates metabotropic glutamate receptor presynaptic inhibition of excitatory transmission and vulnerability to cocaine seeking. J Neurosci. 2005;25:6389-93.

65. Wolf ME. The Bermuda Triangle of cocaine-induced neuroadaptations. Trends Neurosci. 2010;33:391-8.

66. Baker DA, Xi Z-X, Shen H, Swanson CJ, Kalivas PW. The origin and neuronal function of $<$ em $>$ in vivo</em $>$ nonsynaptic glutamate. J Neurosci. 2002;22:9134-41.

67. Kalappa BI, Anderson CT, Goldberg JM, Lippard SJ, Tzounopoulos T. AMPA receptor inhibition by synaptically released zinc. Proc Natl Acad Sci USA. 2015;112:15749-54.

68. Anderson CT, Radford RJ, Zastrow ML, Zhang DY, Apfel UP, Lippard SJ, et al. Modulation of extrasynaptic NMDA receptors by synaptic and tonic zinc. Proc Natl Acad Sci USA. 2015;112:E2705-2714.

69. Fouyssac M, Belin D. Beyond drug-induced alteration of glutamate homeostasis, astrocytes may contribute to dopamine-dependent intrastriatal functional shifts that underlie the development of drug addiction: a working hypothesis. Eur J Neurosci. 2019;50:3014-27.

70. Blakemore $\amalg$, Trombley PQ. Mechanisms of zinc modulation of olfactory bulb AMPA receptors. Neuroscience. 2019;410:160-75.

71. Zinsmaier AK, Dong Y, Huang YH. Cocaine-induced projection-specific and cell type-specific adaptations in the nucleus accumbens. Mol Psychiatry. 2021. In press.

72. Tomko RL, Jones JL, Gilmore AK, Brady KT, Back SE, Gray KM. N-acetylcysteine: a potential treatment for substance use disorders. Curr Psychiatr. 2018;17:30-55.

73. Pace NJ, Weerapana E. Zinc-binding cysteines: diverse functions and structural motifs. Biomolecules. 2014;4:419-34.

74. Wolfram T, Schwarz M, Reuß M, Lossow K, Ost M, Klaus S, et al. N-Acetylcysteine as modulator of the essential trace elements copper and zinc. Antioxidants. 2020;9:1117.

75. Bonaventura J, Quiroz C, Cai NS, Rubinstein M, Tanda G, Ferre S. Key role of the dopamine D4 receptor in the modulation of corticostriatal glutamatergic neurotransmission. Sci Adv. 2017;3:e1601631.

76. Skalny AV, Skalnaya MG, Grabeklis AR, Skalnaya AA, Tinkov AA. Zinc deficiency as a mediator of toxic effects of alcohol abuse. Eur J Nutr. 2018;57:2313-22.

77. Lepping $P$, Huber $M$. Role of zinc in the pathogenesis of attention-deficit hyperactivity disorder: implications for research and treatment. CNS Drugs. 2010;24:721-8.

\section{ACKNOWLEDGEMENTS}

The authors thank Dr. Thanos Tzounopoulos (University of Pittsburgh) for sharing ZnT3 knockout mice, Dr. Richard Dyck (University of Calgary) for advice regarding $\mathrm{Zn}^{2+}$ staining, Dr. Yavin Shaham (NIDA) for experimental advice in behavioral 
experimentation and for manuscript comments, and Dr. Marisela Morales (NIDA), Dr. Antonio Lanzirotti, Dr. Keith Jones and William Rao at the National Synchrotron Light Source (NSLS) X26a Beamline at Brookhaven National Laboratory for instrumentation access.

\section{AUTHOR CONTRIBUTIONS}

JLG, JB, SL, DLM, KMW, MLC, LAR, RJE, CJ, GB, JK, MP, MB, ZX, GT, OS, and MM designed and/or performed experiments and/or analyzed data. ZX, GT, and MM supervised work. JLG, JB, and MM wrote the paper with input from all coauthors.

\section{FUNDING}

This work was supported by the NIDA Intramural Research Program (DA000069), the NIDA Medication Development Program (DA000611) and the Department of Energy (DOE) GeoSciences grant DE-FG02-92ER14244. Open Access funding provided by the National Institutes of Health (NIH).

\section{COMPETING INTERESTS}

The authors declare no competing interests.

\section{ADDITIONAL INFORMATION}

Supplementary information The online version contains supplementary material available at https://doi.org/10.1038/s41398-021-01693-0.
Correspondence and requests for materials should be addressed to Michael Michaelides.

Reprints and permission information is available at http://www.nature.com/ reprints

Publisher's note Springer Nature remains neutral with regard to jurisdictional claims in published maps and institutional affiliations.

(i) Open Access This article is licensed under a Creative Commons cc) Attribution 4.0 International License, which permits use, sharing, adaptation, distribution and reproduction in any medium or format, as long as you give appropriate credit to the original author(s) and the source, provide a link to the Creative Commons license, and indicate if changes were made. The images or other third party material in this article are included in the article's Creative Commons license, unless indicated otherwise in a credit line to the material. If material is not included in the article's Creative Commons license and your intended use is not permitted by statutory regulation or exceeds the permitted use, you will need to obtain permission directly from the copyright holder. To view a copy of this license, visit http://creativecommons. org/licenses/by/4.0/.

This is a U.S. government work and not under copyright protection in the U.S.; foreign copyright protection may apply 2021 